\title{
Strombolian eruptions and dynamics of magma degassing at Yasur
}

\section{Volcano (Vanuatu)}

Julia Woitischek ${ }^{1,2}$, Andrew W. Woods ${ }^{1,2}$, Marie Edmonds ${ }^{1}$, Clive Oppenheimer ${ }^{3}$, Alessandro Aiuppa $^{4}$, Tom D. Pering ${ }^{5}$, Tehnuka Ilanko ${ }^{5}$, Roberto D'Aleo ${ }^{6}$, Esline Garaebiti ${ }^{7}$

${ }^{1}$ Department of Earth Sciences, University of Cambridge, Downing Street, Cambridge, CB2 3 EQ, United Kingdom

${ }^{2}$ BP Institute, University of Cambridge, Madingley Road, Cambridge, CB3 OEZ, United Kingdom

${ }^{3}$ Department of Geography, University of Cambridge, Downing P1, Cambridge, CB2 3EN, United Kingdom

${ }^{4}$ Dipartimento di Scienze della Terra e del Mare (DiSTEM), Universita degli Studi di Palermo, Via Archirafi 36, Palermo 90123, Italy

${ }^{5}$ Department of Geography, University of Sheffield, Winter Street, Sheffield, S10 2TN, United Kingdom

${ }^{6}$ INGV, Sezione di Palermo, Via Ugo la Malfa 153, 90146, Palermo, Italy

${ }^{7}$ Vanuatu Meteorology and Geohazards Department, Lini Highway, Port Vila, Vanuatu

Highlights:

- FTIR and Multi-GAS measurements at Yasur Volcano constrain volcanic gas compositions

- A new model is proposed to explain the cyclic variation in gas geochemistry at Yasur, based on rupture and reforming of a crystal-rich plug.

- High fluxes of volcanic gases have persisted at Yasur Volcano for decades.

\section{Abstract}

Open vent basaltic volcanoes account for a substantial portion of the global atmospheric outgassing flux, largely through passive degassing and mild explosive activity. We present volcanic gas flux and composition data from Yasur Volcano, Vanuatu collected in July 2018. The average volcanic plume chemistry is characterised by a mean molar $\mathrm{CO}_{2} / \mathrm{SO}_{2}$ ratio of 2.14 , $\mathrm{H}_{2} \mathrm{O} / \mathrm{SO}_{2}$ of 148 and $\mathrm{SO}_{2} / \mathrm{HCl}$ of 1.02 . The measured mean $\mathrm{SO}_{2}$ flux in the period of $6^{\text {th }}$ to $9^{\text {th }}$ July is $4.9 \mathrm{~kg} \mathrm{~s}{ }^{-1}$. Therefore, the mean fluxes of the other species are $7.5 \mathrm{~kg} \cdot \mathrm{s}^{-1} \mathrm{CO}_{2}, 208 \mathrm{~kg} \cdot \mathrm{s}^{-1}$ $\mathrm{H}_{2} \mathrm{O}$ and $4.8 \mathrm{~kg} \cdot \mathrm{s}^{-1} \mathrm{HCl}$. The degassing regime at Yasur volcano ranges from 'passive' to 'active' styles, with the latter including Strombolian activity and spattering. Gases emitted during active degassing are enriched in $\mathrm{SO}_{2}$ over $\mathrm{HCl}$ and $\mathrm{CO}_{2}$ over $\mathrm{SO}_{2}$ relative to passive degassing, with $\mathrm{CO}_{2} / \mathrm{SO}_{2}$ ratios of $2.85 \pm 0.17, \mathrm{SO}_{2} / \mathrm{HCl}$ of $1.6 \pm 0.22$, and $\mathrm{H}_{2} \mathrm{O} / \mathrm{SO}_{2}$ of $315 \pm$ 78.8. Gases emitted during passive degassing have $\mathrm{CO}_{2} / \mathrm{SO}_{2}$ ratios of $1.96 \pm 0.12, \mathrm{SO}_{2} / \mathrm{HCl}$ of 
$0.50 \pm 0.07$ and $\mathrm{H}_{2} \mathrm{O} / \mathrm{SO}_{2}$ of $174 \pm 43.5$. We use a model of volatile degassing derived from melt inclusion studies (Metrich et al., 2011), combined with our observations of chemical variations in the outgassing bubbles to propose a mechanism for magma degassing in the conduit at Yasur. We envisage a shallow conduit filled with crystal-rich magma, forming a viscous and mobile plug that develops an effective yield strength from the surface to a depth of at least $2000 \mathrm{~m}$, in which bubbles are trapped, grow, ascend towards the surface and burst in a typical Strombolian eruption. Deeper bubbles released during active degassing are enriched in $\mathrm{CO}_{2}$ and $\mathrm{SO}_{2}$ compared to bubbles released during 'passive degassing', which are sourced from close to the surface, and are, consequently, HCl-rich.

Keywords: basaltic open vent volcanoes, Strombolian activity, Yasur, crystal content in magma, gas fluxes, magma fluxes.

\section{Introduction}

Basaltic volcanoes contribute a large proportion of the volcanic gas flux to the atmosphere (Burton et al., 2013, Aiuppa et al., 2019). Six of the ten most prolific volcanic outgassers are basaltic open-vent volcanoes (Burton et al., 2013, Carn et al., 2017), wherein degassing takes place from the free magma surface at an open vent. Characterising this style of degassing is important in order to monitor volcanic hazard, understand their role in the geochemical cycling of volatiles between the interior and atmosphere on a planetary scale, and quantify the volumes and depths of the magma bodies responsible for driving the degassing. The activity observed at basaltic open-vent volcanoes is characterised by a range of degassing regimes, from passive degassing and lava lake activity, through Strombolian activity, lava fountaining and subPlinian eruptions (e.g. Blackburn et al, 1976, Williams, 1983, Walker et al., 1984, Coltelli et al.,1995, Allard et al., 2005, Burton et al., 2007a, Aiuppa et al., 2010, Ilyinskaya et al., 2012, Tamburello et al., 2012). These styles of activity are dependent, to varying degrees, on magma rise speed, magma volatile content, bubble-melt separation depth, bubble ascent velocity and bulk magma viscosity (Wilson and Head, 1981, 1983, Parfitt and Wilson, 1995, Slezin, 2003, Houghton and Gonnerman, 2008).

Strombolian activity is associated with the bursting of large bubbles termed gas slugs (or Taylor bubbles) at the vent or lava lake surface (Blackburn et al., 1976, Sparks, 1978, Burton et al., 2007a, Houghton and Gonnermann, 2008, Parfitt, E.A., 2004, Pering et al., 2015). It is common at basaltic volcanoes because the comparatively low viscosity of the melt $\left(10-10^{4} \mathrm{~Pa} \cdot \mathrm{s}\right)$ allows 
gas-melt segregation and bubble coalescence processes on the timescale of magma rise (Batchelor, 1967, Jaupart and Vergniolle, 1988, 1989, Woods and Cardoso, 1997, Francis and Oppenheimer, 2004, Parfitt and Wilson, 2008, James et al., 2009,). Gas slugs can range in length up to $200 \mathrm{~m}$ (Taddeucci et al., 2010, Del Bello et al., 2012,). The rise of a large gas bubble or slug is often accompanied by an increase in the height of the magma surface until the bubble bursts at the surface and releases a large volume of magmatic gas, ejecting metrescale molten magma fragments and ash into the air (Taddeucci et al., 2012a,b, Gaudin et al., 2016, Houghton et al., 2008). Typical volumes of gas released by a single bubble at Stromboli vary from $10-1000 \mathrm{~m}^{3}$ (Vergniolle and Brandeis, 1996, Ripepe and Marchetti, 2002, Mori and Burton, 2009, Del Bello et al., 2012, Pering and McGonigle, 2018). Another key characteristic of Strombolian eruptions is periodic or quasi-periodic, short-duration eruptions (5-6 events of 5-10 seconds duration per hour) (Allard et al., 1994, Ripepe and Harris., 2008, Taddeucci et al., 2012a,b, Houghton et al., 2016, Gaudin et al., 2016).

Among the volcanoes that exhibited Strombolian behaviour are Stromboli (Italy), Pacaya (Guatemala), Erebus (Antarctica), Villarrica (Chile), Reventador (Ecuador), Arenal (Costa Rica) and Yasur (Vanuatu) (Ntepe and Dorel, 1990, Neuberg et al., 1994, Vergniolle and Brandeis, 1996, Seyfriend and Hort, 1999, Chouet et al., 1999,2003, Urbanski et al., 2002, Hort et al., 2003, Oppenheimer et al., 2006, Ripepe et al., 2007; Patrick et al., 2007, Gaudin et al., 2014, Ripepe et al., 1993). Strombolian activity is characterised by discrete, rhythmic, mild to moderate bursting of over-pressurised bubbles lasting for a few seconds, with a low eruption rate of a variety of pyroclastics including lapilli, bombs, ash and lithic blocks (Rosi et al., 2013, Houghton et al., 2016). This typical activity can be subdivided qualitatively into normal, major and paroxysmal kinds of explosion (Rosi et al., 2013) or, based on the products of the explosion, into ballistic- or ash-dominated explosions (Rosi et al., 2013, Patrick et al., 2007, Gaudin et al., 2017). The transition between these different types of eruption is still not well understood but might correlate with the slug size and the presence of a layer of degassed and cooled magma on top (Del Bello et al., 2015, Capponi et al., 2016, Spina et al., 2019b, Oppenheimer et al., 2020)

Between Strombolian eruptions, many open vent basaltic volcanoes exhibit persistent degassing (Andres and Kasgnoc, 1998, Aiuppa et al., 2008, Burton et al., 2000, Burton et al., 2013, Carn et al., 2017, Girona et al., 2015,), which is poorly understood. Persistent degassing 
has been linked to magma convection in the conduit, whereby gas-rich magma rises and outgasses, then denser, gas-poor magma sinks back down the conduit, supplying gas to the atmosphere without eruption of magma (Francis et al., 1993, Allard et al., 1994, Kazahaya et al., 1994, Stevenson and Blake 1998, Burton et al., 2007b, Huppert and Hallworth., 2007, Beckett et al., 2014). The rate of magma convection for Stromboli, for example, has been proposed to range from $300-1300 \mathrm{~kg} \cdot \mathrm{s}^{-1}$ (Harris and Stevenson, 1997), to account for the flux of magmatic gases emitted from the volcano (Allard et al., 1994). The style of magma flow in the conduit may be described either as Poiseuille flow (steady, axisymmetric flow through a pipe) or, if the conduit is inclined, bubbly magma will ascend along the upper wall and degassed magma back down along the lower wall (James et al., 2004); or as the ascent of undegassed magma spheres through stagnant, degassed magma (Koyaguchi, 1985, 1987, Kazahaya et al., 1994). In order to sustain surface degassing continuously for long timescales (e.g. over $10^{3}$ years at Stromboli Volcano), a continuous input of new volatile-rich magma is required to be supplied to the shallow plumbing system (Francis et al., 1993; Allard et al., 2005, Burton et al., 2007b, Girona et al., 2015,).

Typical models of magma convection in a conduit are simplified models of two-phase exchange flows, in which melt is assumed to rise to a specific depth, degas and then return to a deeper reservoir. In practice, convection processes will be more complex due to crystallisation and the exsolution of gas from melt during magma ascent. An increase in magma crystallinity can dramatically affect the rheological properties of the ascending magma and therefore, also influence eruption style (Sparks, 1978, Belien et al., 2010, Cimarelli, et al., 2011, Oppenheimer et al., 2015, Barth et al., 2019). The presence of a crystal phase in a liquid may strongly influence the mobility of bubbles, as shown in recent studies involving threephase analogue experiments (Belien et al., 2010; Oppenheimer et al., 2015, 2020, Barth et al., 2019). In a densely packed suspension, outgassing occurs as bursts or puffs because the granular network in the particle pack resists bubble growth and instead promotes bubble coalescence and the formation of permeable pathways (Oppenheimer et al. 2015). Similar experimental results were presented by Barth et al. (2019), who proposed that the episodic gas release during Strombolian eruptions occurs because crystalline mush in the shallow plumbing system acts as a valve to control a continuous gas supply. In their model, the size of the gas pocket depends on the overpressure within the bubble prior to the tensile failure of the particlerich suspension. These experiments provide new insights into the mechanisms linking degassing cyclicity to the presence of crystals. Numerical simulations performed by Parmigiani 
et al., $(2014,2016,2017)$ focusses on the interaction between bubbles and crystals at a pore scale. In their simulations, bubbles accumulate in the magma until they overcome the capillary pressure within the pores in the crystalline magma, which promotes bubble coalescence.

140 Additionally, the authors propose that the bubble transport dynamics changes with increasing 141 crystal volume fraction: from suspension and channel formation to the arrest of bubbles. In 142 analogue experiments, Pistone et al., (2017) observed that at high crystal fractions, gas exsolution can generate sufficient overpressure to form microfractures in the magma. Spina et al, (2019 b) illustrated the strong control of crystallinity on gas permeability and mobility in analogue magmas in a series of experiments.

146 Yasur magmas typically contain > 30 vol. \% crystals (Metrich et al., 2011) and thus is an ideal 147 natural laboratory to study the effect of the crystal phase on degassing dynamics. In this paper, we present the results of a field campaign to measure the flux and composition of volcanic gases emitted from Yasur Volcano (Vanuatu) in July 2018. We quantify gas chemistry changes over timescales of seconds during small-scale Strombolian activity, passive degassing, and recharge periods, and relate the gas composition to degassing mechanisms (e.g. 'open' vs 'closed' degassing and depth of gas-melt decoupling). We analyse high frequency time-series of Yasur's emitted plume composition and flux collected by open-path Fourier transformed infrared spectrometer (OP-FTIR) and multicomponent volcanic gas analyser (MultiGAS) and calculate gas and magma fluxes based on measurements by Ilanko et al., 2020. We also correlate several hours of video footage with the corresponding gas data to elucidate differences in gas composition associated with explosion and outgassing dynamics. This footage was used to document morphological changes in the crater and to count the frequency of bubble bursts. We use a previously published degassing model based on melt inclusion data (Metrich et al., 2011) to reconstruct volatile partitioning into an exsolved phase during magma ascent from $200 \mathrm{MPa}$ to the surface, and incorporate the effect of crystallization in the shallow conduit. We use the observed $\mathrm{CO}_{2} / \mathrm{SO}_{2}$ ratio combined with melt inclusion systematics to infer the primary minimum melt $\mathrm{CO}_{2}$ content of the Yasur melts. These model results are compared with our surface gas measurements to infer the mixing (coalescence) processes and approximate depths of gas-melt separation for different modes of outgassing with the aim to better understand Yasur's shallow plumbing system. We consider whether the high crystallinity of Yasur's magma influences the outgassing style. 
169 Mount Yasur Volcano (361 m a.s.l) is a basaltic-andesitic volcano on Tanna island, in the

170 archipelago of Vanuatu in the Southwest Pacific Ocean (figure 1). Tanna is located in the 171 central part of the New Hebrides Island Arc and approximately $150 \mathrm{~km}$ above the Benioff zone

172 caused by the subduction of the Indo-Australian underneath the Pacific plate (Carney and 173 Macfarlane, 1979; Louat et al., 1988, Bani and Lardy, 2007, Spina et al., 2016,). The 174 convergence rate varies from $90-120 \mathrm{~mm}$ per year and is controlled by the dynamics of the 175 subduction zone and the back-arc North-Fiji basin (Taylor et al., 1995, Vergniolle and Metrich, 176 2016). Yasur has two summit craters, named North and South crater. Previous studies refer to 177 three active vents (A, B, C) (e.g. Bani et al., 2013) but locals reported the permanent existence 178 of four vents named Kraesun (South Crater, vent B in Bani et al., 2013), Wei Wei (South Crater, 179 vent A in Bani et al., 2013), Kaunaung (North Crater, vent C in Bani et al., 2013) and Kasmiren 180 (North Crater, vent $\mathrm{C}$ in Bani et al., 2013). The volcano exhibits long-lived, persistent 181 degassing, which may have been maintained over the last 1400 years (Metrich et al., 2011, 182 Vergniolle and Metrich, 2016), with sporadic Strombolian activity (Oppenheimer et al., 2006, 183 Bani et al., 2013, Gaudin et al., 2014, Battaglia et al., 2016, Vergniolle and Metrich, 2016). 

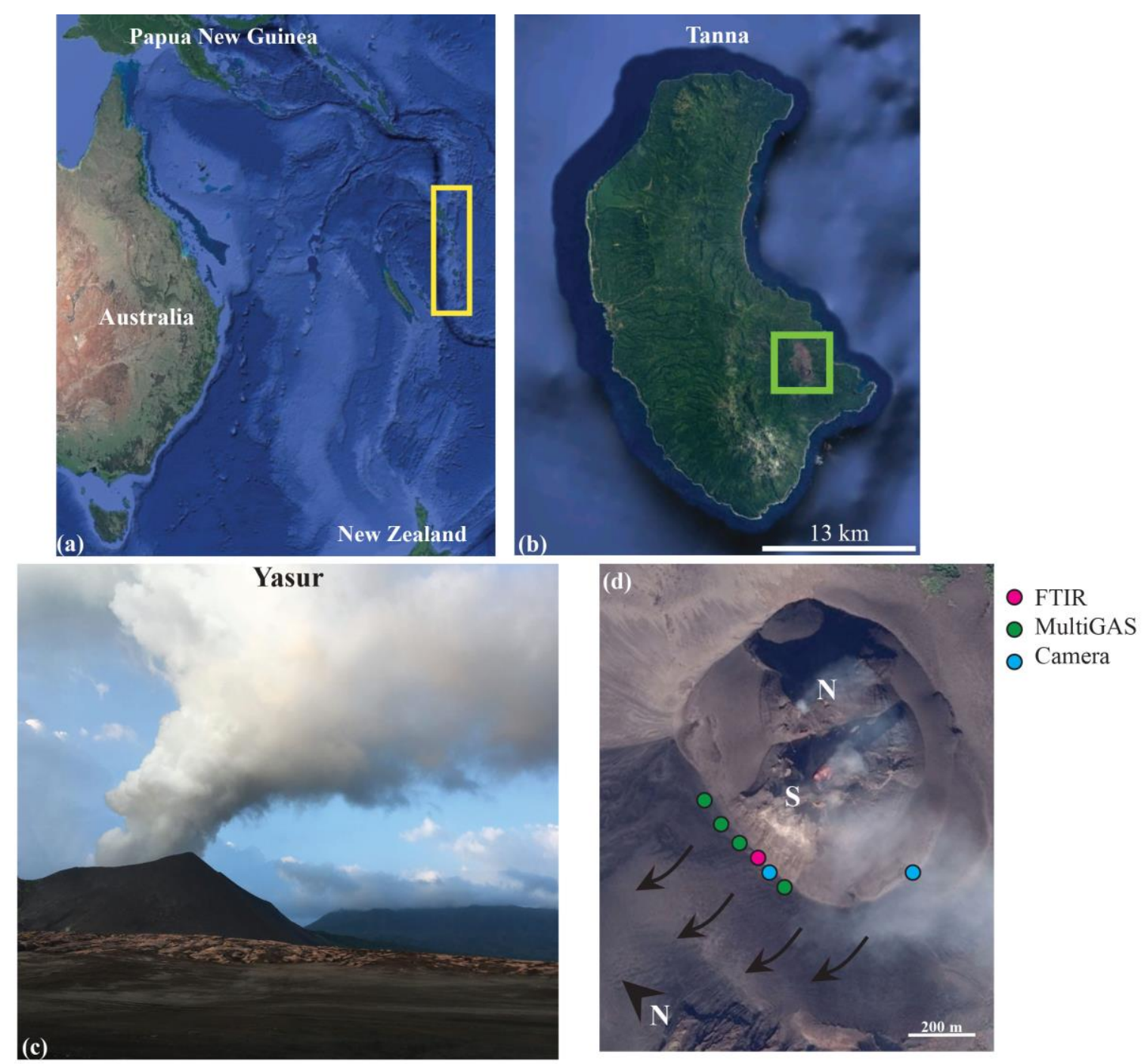

Figure 1 (a) Location of Vanuatu in the southwestern Pacific (yellow rectangle (b) Tanna island with Yasur located in the eastern part of the island (green rectangle),(c) Yasur Volcano, one of the most active volcanoes in Vanuatu and the world,(d) bird's eye view of North (N) and South (S) crater of Yasur with the position of the equipment along the crater rim pointing into the South crater: FTIR (red circle), MultiGAS (green circle) and cameras (blue circle). The arrows pointing in the west showing the prevailing plume direction.

199 Previous studies of volcanic outgassing at Yasur combined a high-speed thermal camera with an infrasonic sensor (Spina et al., 2016) and distinguished between two explosion classes in the South crater based on distinct spectral features and waveforms: minor explosions caused by small and continuously-bursting over-pressurised gas bubbles; and larger events, characterized as Strombolian eruptions. According to Spina et al. (2016), these kinds of eruptive events are decoupled and represent distinct mechanisms of degassing. Another classification of Yasur's explosions in both North and South crater (Meier et al., 2016) based on a multi-parametric dataset of doppler radar, infrared imagery, and infrasound, categorised 
207

208

209

210

211

212

213

214

215

216

217

218

219

220

221

222

223

224

225

226

227

228

229

230

231

232

233

234

235

236

237

two explosion styles: ash-rich, and ash-free. A classification based solely on infrared thermal imaging in the South crater (Bani et al., 2013) differentiates between low and high energy events, and suggests that low-energy events originate in the shallow conduit, whereas the high energy events originate deeper and are associated with the bursting of slugs. Seismic (LP events) reveal that Strombolian activity is associated with signals originating at $700-1200 \mathrm{~m}$ below the summit (Battaglia et al., 2016). Oppenheimer et al (2006) identified, using OP-FTIR measurements, variations in the $\mathrm{SO}_{2} / \mathrm{HCl}$ molar ratio between 'passive' (degassing between explosions) and 'active' degassing (Strombolian eruptions) in the South crater. Gases emitted during Strombolian explosions at Yasur in 2005 were characterised by molar $\mathrm{SO}_{2} / \mathrm{HCl}$ ratios of up to 30 whereas those associated with passive degassing had a typical ratio between about 1.5 and 2.5 (Oppenheimer et al., 2006). The differences in the $\mathrm{SO}_{2} / \mathrm{HCl}$ ratio were explained using two gas sources: a gas rich in $\mathrm{SO}_{2}$, sourced at a greater depth where larger gas slugs are formed, and the shallower source rich in $\mathrm{HCl}$ and responsible for passive degassing (Oppenheimer et al., 2006).

Studies quantifying the volatile contents of melt inclusions $\left(\mathrm{H}_{2} \mathrm{O}, \mathrm{CO}_{2}, \mathrm{~S}, \mathrm{Cl}\right)$ combined with MELTS modelling (Ghiorso and Sack, 1995) have suggested that extensive degassing of the melt begins at 4 or $5 \mathrm{~km}$ beneath the surface at Yasur (Metrich et al., 2011). In this part of the plumbing system, the basaltic-trachyandesitic magma crystallizes extensively (by > 30 vol. \%), predominantly forming plagioclase feldspar (Metrich et al., 2011).

\section{Ground-based gas measurements in October 2007 revealed that Yasur was emitting > 155} $\mathrm{kg} \cdot \mathrm{s}^{-1} \mathrm{H}_{2} \mathrm{O}, 7.9 \mathrm{~kg} \cdot \mathrm{s}^{-1}$ of $\mathrm{SO}_{2}, 9.7 \mathrm{~kg} \cdot \mathrm{s}^{-1} \mathrm{CO}_{2}, 1.9 \mathrm{~kg} \cdot \mathrm{s}^{-1} \mathrm{HCl}$ and $0.3 \mathrm{~kg} \cdot \mathrm{s}^{-1} \mathrm{HF}$ (Metrich et al., 2011). The $\mathrm{SO}_{2}$ emission rate derived from satellite-based Ozone Mapping Instrument (OMI) measurements from 2000 to 2015 averaged $16.3 \mathrm{~kg} \cdot \mathrm{s}^{-1}$ (Carn et al., 2017). As a result, Yasur ranks at number 11 in a list of 91 degassing volcanic $\mathrm{SO}_{2}$ sources (Carn et al., 2017). $\mathrm{SO}_{2}$ flux measurements during field campaigns in 2004, 2005 and 2007 reveals fluxes ranging from 1.9 to $14.5 \mathrm{~kg} \cdot \mathrm{s}^{-1} \mathrm{SO}_{2}$ in 2004 and 2005 (Bani and Lardi, 2007) and $7.9 \pm 3.8 \mathrm{~kg} \cdot \mathrm{s}^{-1} \mathrm{SO}_{2}$ in 2007 (Metrich et al., 2011).

\section{Methods}

Volcanic gas composition and flux measurements were carried out on Yasur Volcano from 6 to 16 July 2018 using an open path Fourier transform infrared spectrometer (OP-FTIR), Multi- 

with a ZnSe beam splitter and a Stirling engine-cooled detector was deployed on the southern crater rim (location shown on figure 1e), powered by a 20 Ah battery. A laptop running AutoQuant Pro 4.5 software, connected to the FTIR, controlled data acquisition. The spectrometer was placed on a tripod and positioned to collect infrared radiation from a hot vent in the South crater (figure 1). The nominal field of view of the spectrometer is $20 \mathrm{mrad}$. The distance between the infrared source and the spectrometer was approximately $300 \mathrm{~m}$. The volcanic gases from the multiple different vents mixed inside the crater, such that measurements of gases from only one particular vent was not possible. Analysis of FTIR spectra is based on the principles of absorption spectroscopy. We used the HITRAN database 2008, which provides the absorption coefficients (Rothman et al., 2009).

250

251

252

253

254

255

256

257

258

259

260

261

262

263

Spectra were acquired during the following intervals (in GMT time): 06:41-06:56 h (set 1), 08:19-08:24 h (set 2) and 08:56-09:03 (set 3). All interferograms were collected at a time step of 1 second and a nominal $0.5 \mathrm{~cm}^{-1}$ spectral resolution. In total 698 spectra were collected. Column amounts of $\mathrm{SO}_{2}$, and $\mathrm{HCl}$ were retrieved from single beam spectra using a code that simulates and fits atmospheric transmittance in discrete wavebands (Burton et al., 2000). The code gives for each selected gas a 'goodness of fit', which provide information about how close the computed and the measured spectra fit. The average fitting error for $\mathrm{SO}_{2}$ is $4.8 \%$ (standard deviation of the average error, sd: $\pm 0.63 \%$ ) and $6.9 \%$ (sd: $\pm 0.86 \%$ ) for $\mathrm{HCl}$. Laboratory experiments were carried out in previous studies to validate the precision of the measurements using primary gas standards, suggesting accuracies of order of $5 \%$ for retrieved column amounts of $\mathrm{SO}_{2}$ and $\mathrm{CO}$ (Horrocks et al., 2001,). The wavebands selected to retrieve volcanic gas species were: 2020 to $2100 \mathrm{~cm}^{-1}$ for $\mathrm{H}_{2} \mathrm{O}$ and $\mathrm{CO}_{2}, 2430$ to $2530 \mathrm{~cm}^{-1}$ for $\mathrm{SO}_{2}$ and 2680 to $2835 \mathrm{~cm}^{-1}$ for $\mathrm{HCl}$. The uncertainty on FTIR gas ratios was calculated by propagating the errors on individual retrievals i.e. the root of the sum of the individual maximum fitting errors. The maximum fitting error for $\mathrm{SO}_{2}$ was of $8.7 \%$ and for $\mathrm{HCl}$ is was of $10.4 \%$. Therefore, the calculated error for this $\mathrm{SO}_{2} / \mathrm{HCl}$ ratio is $14 \%$.

A multicomponent gas analyser system (MultiGAS; Aiuppa et al., 2005, 2010, Shinohara, 2005) was used to measure the composition of the volcanic plume (sourced from both, the North and South crater; figure 1e) from 6 to 16 July 2018. The Multi-GAS hosts infrared sensors (LI-840 NDIR closed-path spectrometer, measurement range 0-3000 ppmv for $\mathrm{CO}_{2}$ accuracy, $\pm 1.5 \%$ ), and electrochemical sensors (model 3ST/F, Cod.TD2D-1A,City 
271 Technology Ltd., calibration range, 0-30 ppmv; repeatability 1\%) for $\mathrm{SO}_{2}$. The infrared and

272 the electrochemical sensors are protected by a pelican case and the volcanic plume is pumped

273 at a rate of $0.6 \mathrm{~L} \mathrm{~min}^{-1}$ to the sensors. The sensors are connected to a data logger that is

274 programmed to capture measurements of the plume at a sampling rate of $1 \mathrm{~Hz}$ (Aiuppa et al.,

275 2010). The Multi-GAS was placed at the southern and western rim of Yasur (figure 1e) and

276 powered by lithium battery. It measured the concentration of the volcanic gases by integrating

277 the infrared sensor for $\mathrm{CO}_{2}$, the electrochemical sensors for $\mathrm{SO}_{2}$ and temperature, pressure and

278 relative humidity of $\mathrm{H}_{2} \mathrm{O}$. MultiGAS time series were post-processed by using the Ratiocalc

279 software (Tamburello et al., 2015). Uncertainties in derived molar ratios, based on laboratory

280 test results are, for $\mathrm{CO}_{2} / \mathrm{SO}_{2}$ with $\mathrm{SO}_{2}>0.16 \mathrm{~mol}, \pm 6 \%$ and with $\mathrm{SO}_{2}<0.16 \mathrm{~mol}$ the error

281 increases to $\pm 12 \%$ (Liu et al., 2019). Errors for $\mathrm{H}_{2} \mathrm{O} / \mathrm{SO}_{2}$ ratios, based on laboratory tests, are

$282 \pm 25 \%$. For this study, we obtained 7523 measurements.

283

284 Ultraviolet (UV) cameras (PiCam; Wilkes et al., 2016; 2017) were used to measure the emission rate of $\mathrm{SO}_{2}$ during the same time period (the methods and full results are described and presented in Ilanko et al.,2020). The method is based on the characteristic absorption of scattered UV sunlight by $\mathrm{SO}_{2}$ between 300 and $320 \mathrm{~nm}$ (Mori and Burton, 2006, Kantzas et al., 2010, Kern et al., 2015). $\mathrm{SO}_{2}$ emission rates derived from the PiCam data in the period of $6^{\text {th }}$ to $9^{\text {th }}$ July 2018 were used to derive fluxes of the other gas species (Ilanko et al., 2020). The calculated error for the $\mathrm{HCl}$ flux is $21 \%$ based on propagating errors from the $\mathrm{SO}_{2}$ flux measurement ( $15 \%$, Ilanko et al., 2020) and error on molar $\mathrm{SO}_{2} / \mathrm{HCl}$ (from FTIR).

Lastly, videos and photos captured eruptive activity enabling recording of gas burst frequency, changes in crater morphology and volcanological features of the crater and vents during the period of the field work, using a $12 \mathrm{MP}$ camera at $60 \mathrm{fps}$ (iphone SE). To compare the activity between the North and South craters, a 12 MP camera at 240 fps (go pro hero 7) was installed at the eastern rim to overlook the North and South craters. Both camera positions in figure 1c were used to acquire video images for counting bubble bursts. 


\subsection{Video observations of the South crater}

306

307

308

309

310

311

312

313

314

315

316

317

318

319

320

321

322

323

324

325

326

The number of active vents in the South crater emitting gas and/or magma during the fieldwork varied from 5 to 7 (figure 2). Six vents were observed on 9 July (figure 2a), 7 on 11 July (figure 2b), 6 on 13 July (figure 2c) and 5 on 15 and 16 July (figure 2d). The two principal vents (vent 1 and 2 in figure 2) did not change their position during the field period whereas other minor vents changed their positions and sizes or appeared and disappeared from day to day. Video observations reveal that small bubble bursts generated ejecta that rose a few tens of metres above the vents whereas larger bubble-bursting events generated bombs that were expelled to a height of $>10$ metres above the vents and landed outside the crater. The overall number of large bubble bursts which were counted on the video (and generated ejecta) per second was $4 \pm 0.1 \mathrm{~s}^{-1}$ on $9 \mathrm{July}, 1.3 \pm 0.3 \mathrm{~s}^{-1}$ on $11 \mathrm{July}, 0.8 \pm 0.3 \mathrm{~s}^{-1}$ for 13 July in the morning and $0.7 \pm 0.3 \mathrm{~s}^{-1}$ in the evening and $1.3 \pm 0.1 \mathrm{~s}^{-1}$ for 15 and 16 July. Table 1 shows the overall number of bubbles which were observed in different vents of figure 2 . The average time interval between large bubble bursts (Strombolian explosions) from 8 to 16 July was $54( \pm 44)$ seconds i.e. 0.02 large bubble bursts $\mathrm{s}^{-1}$. One of the principal vents exhibited a consistent style of volcanic activity throughout the measurement period, characterised by Strombolian explosions, which expelled volcanic bombs that occasionally reached the crater rim and were sometimes accompanied by shock waves. The second principal vent showed a different behaviour, exhibiting jet-like gas emission after the bursts that lasted for several seconds. These Strombolian explosions ejected volcanic bombs several hundred meters into the air and were accompanied by shock waves. All the other vents were less active, erupting only a little material (via spattering).

Table 1. Calculated bubble bursts per $s^{-1}$ from vents at Yasur Volcano, Vanuatu in July 2018. The location of the vents are shown in figure 2 over different days. Each calculation is based on 224 to 776 seconds worth of video data.

\begin{tabular}{|c|c|c|c|c|c|c|c|}
\hline \multirow[t]{2}{*}{ day } & \multicolumn{7}{|c|}{ Bubble bursts per second } \\
\hline & Vent 1 & Vent 2 & Vent 3 & Vent 4 & Vent 5 & Vent 6 & Vent 7 \\
\hline $9^{\text {th }}$ July & 0.01 & 0.05 & & 0.06 & 0.02 & & \\
\hline $11^{\text {th }}$ July & 0.009 & 0.03 & 0.40 & & 0.29 & & 0.018 \\
\hline $13^{\text {th }}$ July & 0.003 & 0.17 & 0.43 & 0.16 & 0.45 & 0.01 & \\
\hline $15^{\text {th }} / 16^{\text {th }}$ July & 0.009 & 0.36 & 0.26 & 0.26 & 0.36 & & \\
\hline
\end{tabular}



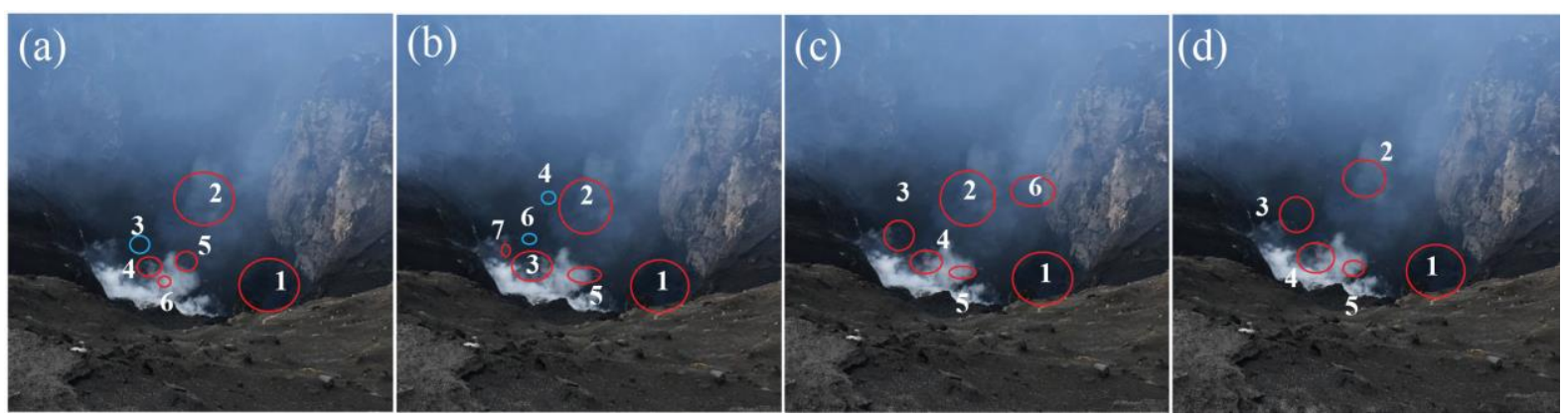

334

Figure 2 Vent location in the crater of Yasur Volcano, Vanuatu, on (a) $9^{\text {th }} \mathrm{July}$, (b) $11^{\text {th }} \mathrm{July}$, (c) $13^{\text {th }}$ July and (d) $15^{\text {th }}-16^{\text {th }}$ July 2018. Estimated field of view is between 200 and $300 \mathrm{~m}$.

MultiGAS results are shown in figure $\mathbf{3}$ and table 2. Across all days, the mean gas concentrations varied between 17.7 and $25.4 \mathrm{ppm} \mathrm{CO}_{2}, 14.1$ to $14.8 \mathrm{ppm} \mathrm{SO}_{2}$ and 364 to 854 ppm $\mathrm{H}_{2} \mathrm{O}$. The mean volcanic gas concentrations in the plume across all four days is: 22.2 ppm $\mathrm{CO}_{2}, 14.4 \mathrm{ppm} \mathrm{SO}$ and $610 \mathrm{ppm} \mathrm{H}_{2} \mathrm{O}$. The mean molar plume composition for all four days is $97.9 \mathrm{~mol} \% \mathrm{H}_{2} \mathrm{O}, 1.44 \mathrm{~mol} \% \mathrm{CO}_{2}$ and $0.66 \mathrm{~mol} \% \mathrm{SO}_{2}$.

(a)

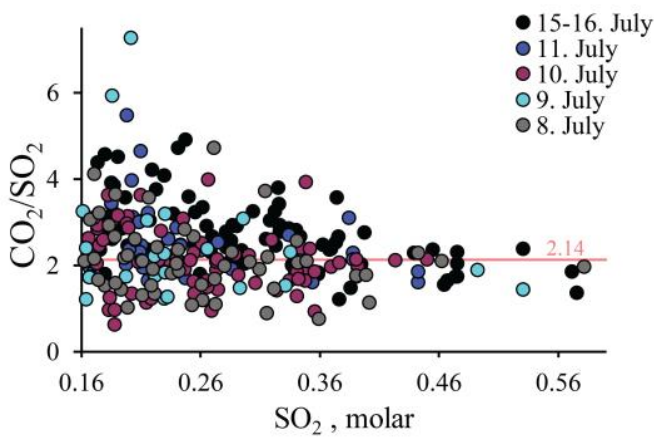

(b)

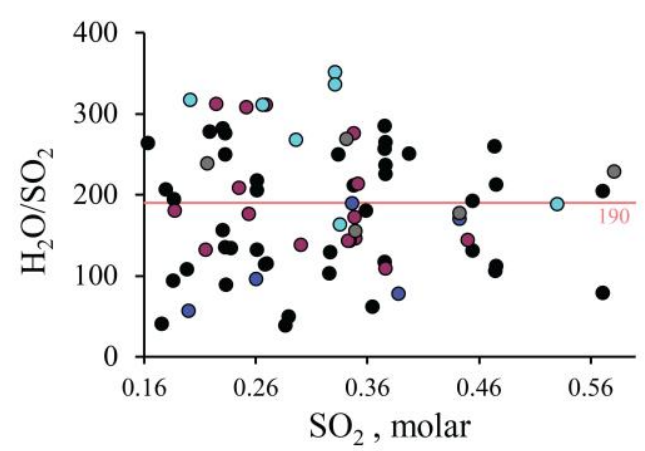

344 Figure 3 Scatter plots of Yasur Volcano's plume gas emissions for $8^{\text {th }}$ to $16^{\text {th }}$ July: (a) Molar

Table 2 shows the mean molar $\mathrm{CO}_{2} / \mathrm{SO}_{2}$ plume ratios for all days, which ranged from 1.80 on 9 July to 2.48 on 16 July. Figure 3a shows $\mathrm{CO}_{2} / \mathrm{SO}_{2}$ ratios plotted against $\mathrm{SO}_{2}$ for single eruption gas peaks recorded in the volcanic plume for each day and shows that $\mathrm{CO}_{2} / \mathrm{SO}_{2}$ were $\mathrm{CO}_{2} / \mathrm{SO}_{2}$ vs. $\mathrm{SO}_{2}$ and (b) Molar $\mathrm{H}_{2} \mathrm{O} / \mathrm{SO}_{2}$ vs. $\mathrm{SO}_{2}$, with the average value of $\mathrm{CO}_{2} / \mathrm{SO}_{2}$ and $\mathrm{H}_{2} \mathrm{O} / \mathrm{SO}_{2}$ ratios (with $\mathrm{SO}_{2}>0.3$ ) marked as a horizontal line, marked with value. Each point corresponds in (a) to a $\mathrm{CO}_{2} / \mathrm{SO}_{2}$ and in (b) to a $\mathrm{H}_{2} \mathrm{O} / \mathrm{SO}_{2}$ peak in the measured data set $\left(\mathrm{CO}_{2} / \mathrm{SO}_{2}: 315\right.$ data points, $\mathrm{H}_{2} \mathrm{O} / \mathrm{SO}_{2}: 86$ data points). Below $\mathrm{SO}_{2}$ concentrations of $0.16 \mathrm{~mol} \%$ the error increases from \pm 6 to $\pm 12 \%$.

consistent from day to day, converging on an overall mean of 2.14 for molar $\mathrm{SO}_{2}$ values $>0.16$ 
(there is a larger spread at lower $\mathrm{SO}_{2}$ values; figure 3a). The daily molar $\mathrm{H}_{2} \mathrm{O} / \mathrm{SO}_{2}$ plume ratios (table 2; figure 3b) are highly variable, ranging from a mean of $89.3 \pm 22.3$ for 11 July and $205 \pm 51.3$ for 16 July with a mean value of 190 for molar $\mathrm{SO}_{2}$ values $>0.3 \mathrm{~mol} \%$, although there is considerable scatter (figure 3b). This variability in molar $\mathrm{H}_{2} \mathrm{O} / \mathrm{SO}_{2}$ is linked strongly to degassing regime: low $\mathrm{H}_{2} \mathrm{O} / \mathrm{SO}_{2}$ is associated with powerful Strombolian eruptions (figure 4a-d).

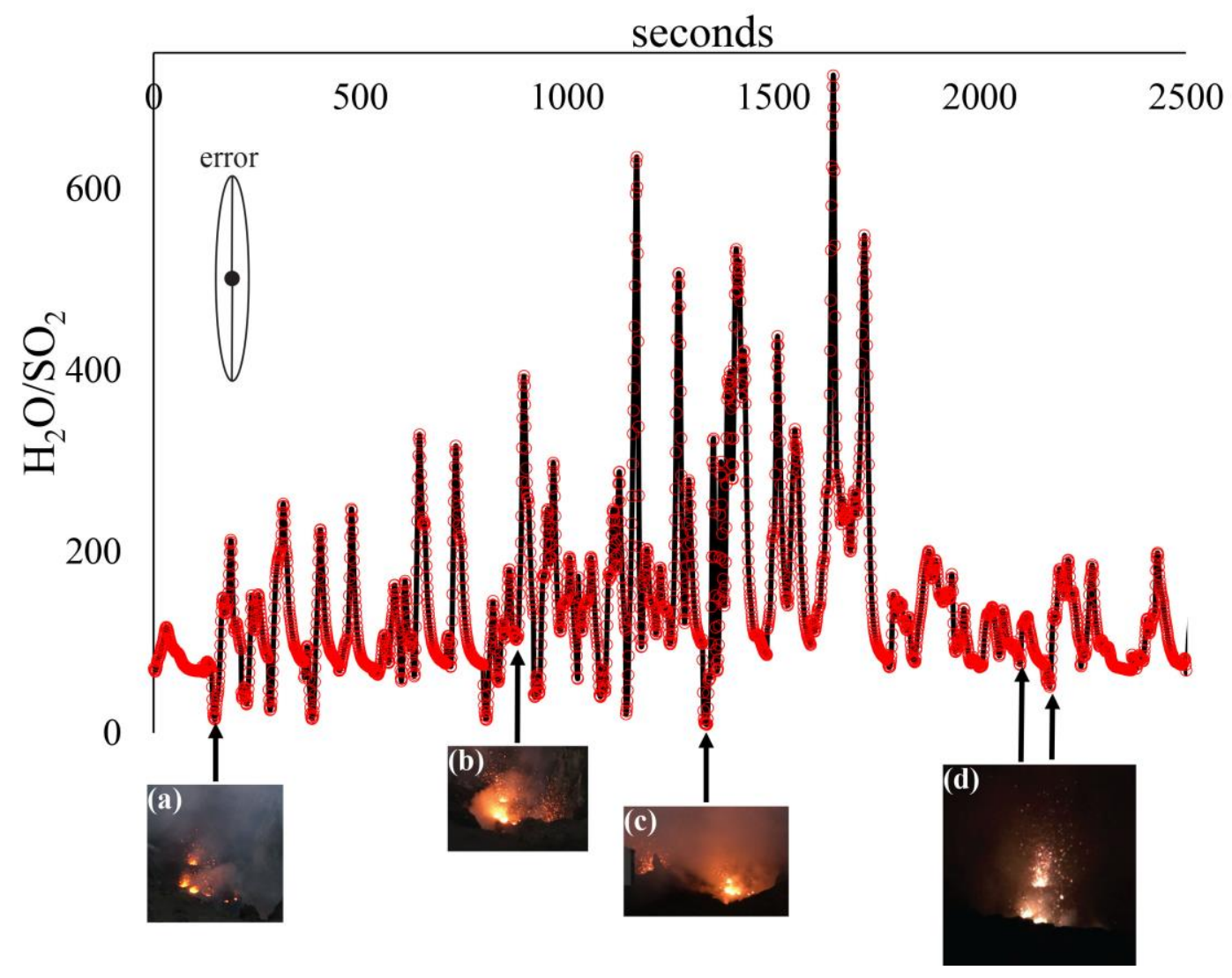

Figure $4 \mathrm{H}_{2} \mathrm{O} / \mathrm{SO}_{2}$ ratio for a Multi-GAS measurement period on $16^{\text {th }}$ July from 5:22 to 6:45 pm. Photos from (a) to (d) show the prevailing different eruption styles in North and South crater: (a, d): spattering activity in the Southern crater, (b) spattering and a mild strombolian eruption in the South crater and (c) mild strombolian eruption in the South crater and powerful strombolian eruption in the North crater. Both, the $\mathrm{H}_{2} \mathrm{O}$ and the $\mathrm{SO}_{2}$ content of the volcanic gases increases from spattering over mild to powerful strombolian eruptions. Eruptive events occur on average every 62 (sd: 30 ) seconds. 
Table 2: Composition of Yasur Volcano's volcanic gas plume measured by MultiGAS on for 9, 10, 11, and 16 July 2018. $n$ : number of measurements including data measurements with $\mathrm{SO}_{2}<0.16 \mathrm{~mol}$, *mean concentration, in ppm (standard deviation), ${ }^{\$}$ molar percentage of each component, ${ }^{\wedge}$ molar ratios.

\begin{tabular}{|l|l|l|l|l|l|l|}
\hline & & 16 July & 11 July & 10 July & 9 July & Mean \\
\hline & $n$ & 4809 & 959 & 1280 & 475 & \\
\hline$*$ Mean concentration & $\mathrm{CO}_{2}$ & $25.4(10.1)$ & $23.3(8.0)$ & $22.2(7.1)$ & $17.7(102)$ & 22.2 \\
\hline & $\mathrm{SO}_{2}$ & $14.8(4.9)$ & $14.4(3.9)$ & $14.1(3.3)$ & $14.4(5.3)$ & 14.4 \\
\hline & $\mathrm{H}_{2} \mathrm{O}$ & $854(274)$ & $364(276)$ & $747(289)$ & $474(389)$ & 610 \\
\hline${ }^{\$}$ Molar composition, \% & $\mathrm{H}_{2} \mathrm{O}$ & 98.3 & 96.4 & 98.3 & 97.7 & 97.9 \\
\hline & $\mathrm{CO}_{2}$ & 1.20 & 2.53 & 1.18 & 1.49 & 1.44 \\
\hline & $\mathrm{SO}_{2}$ & 0.48 & 1.10 & 0.52 & 0.82 & 0.66 \\
\hline${ }^{\wedge}$ Molar ratios & $\mathrm{CO}_{2} / \mathrm{SO}_{2}$ & 2.48 & 2.33 & 2.31 & 1.80 & 2.22 \\
\hline & $\mathrm{H}_{2} \mathrm{O} / \mathrm{SO}_{2}$ & 205 & 89.3 & 189 & 118 & 148 \\
\hline & $\mathrm{H}_{2} \mathrm{O} / \mathrm{CO}_{2}$ & 82.6 & 38.3 & 81.9 & 65.6 & 61.1 \\
\hline
\end{tabular}

381

382

\subsection{Volcanic gas composition from OP-FTIR spectroscopy}

Figure 5 shows the retrieved column amounts for $\mathrm{HCl}, \mathrm{CO}_{2}$, and $\mathrm{SO}_{2}$ from the time series of set 1 from the South crater, which was obtained from the southern crater rim. The record identifies 16 explosions in $360 \mathrm{~s}$ (identified by the rapid increase in gas column amounts) and provides information about changes in gas ratios before and during explosions. We differentiate between active degassing, consisting of intermittent Strombolian explosions and spattering; and passive degassing.

A cyclicity is visible when less active periods are interrupted by explosions, identified by an increase in $\mathrm{SO}_{2}$ and $\mathrm{CO}_{2}$ followed by a decrease (figure 5); explosions occur at the peaks of these cycles. In set 1, explosions 1, 2 and 3 were accompanied by a rise in $\mathrm{SO}_{2}$ column amounts, followed by a decrease to pre-explosion column amounts of $\mathrm{SO}_{2}$ after $\sim 60$ seconds. Smaller explosions $\left(4,5,7,9,10,11,13\right.$, and 16; figure 5) are associated with peaks in $\mathrm{SO}_{2}$ column amounts up to $<4.93 \cdot 10^{19}$ molecules $\cdot \mathrm{cm}^{-2}$ after which $\mathrm{SO}_{2}$ column amounts remain elevated above the pre-explosion level. Explosions 6 and 8 were associated with increases in $\mathrm{SO}_{2}$ column amounts up to $5.26 \cdot 10^{19}$ and $7.07 \cdot 10^{19}$ molecules $\cdot \mathrm{cm}^{-2}$ respectively, which then decreased after the explosions, returning to pre-explosion values after $\sim 20$ seconds. Variation in the concentration-pathlengths of the measured gases could be also caused by the dilution effect of wind gusts in the crater but we regard it unlikely as these changes occur periodically, which is more consistent with the observed volcanic activity. 


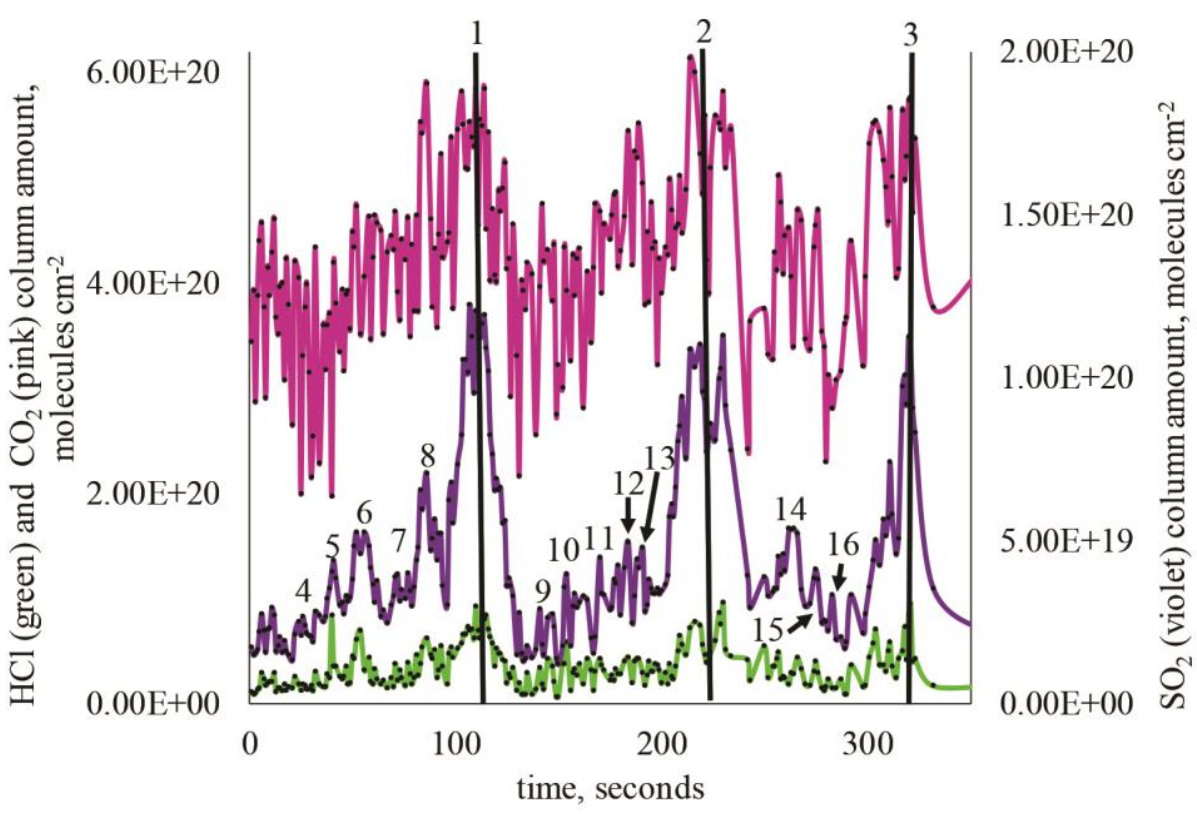

405

Figure 5 Time-series of retrieved column amounts of $\mathrm{HCl}$ (green), $\mathrm{SO}_{2}$ (violet), $\mathrm{CO}_{2}$ (red) for data 406

407 set 1 , in molecules $\cdot \mathrm{cm}^{-2}$. Prominent strombolian explosions are numbered with $1,2,3$ and occur every 100 seconds. Numbered peaks from 4 to 16 mark minor explosive events prior to the strombolian events.

409

410 We observe that active degassing from the South crater is distinguished by a molar $\mathrm{SO}_{2} / \mathrm{HCl}$ ratio between 1 and 1.7 (table 3, figure 6); whereas a $\mathrm{SO}_{2} / \mathrm{HCl}<1$, where $\mathrm{HCl}$ is dominant compared to $\mathrm{SO}_{2}$ in the gas phase, characterises the passive degassing periods (table $\mathbf{3}$, figure 6). In 2005 , Strombolian eruptions in the South crater emitted gas with molar $\mathrm{SO}_{2} / \mathrm{HCl}>30$, and passive degassing was characterised by molar $\mathrm{SO}_{2} / \mathrm{HCl}$ between 1.5 and 2.5 (Oppenheimer et al., 2006). Photos taken in 2005 revealed more violent eruptions occupying the whole crater and with a higher number of volcanic pyroclasts, ejected to greater heights (Oppenheimer et al., 2006). This violent type of eruption was not observed in July 2018. The composition of volcanic gases during active and passive phases is shown in table 3.

Table 3: Mean chemical composition (as molar ratios) of volcanic gases emitted from Yasur Volcano, Vanuatu, during 'active' and 'passive' (non-explosive) phases on 16 July 2019. *South crater measured by OP-FTIR ; ${ }^{+}$Plume of North and South crater measured by MultiGAS. Uncertainties on the mean molar ratios are shown as a \pm range. Number of measurements in each case are shown in brackets.

\begin{tabular}{|c|c|c|}
\hline Molar ratio & Active phase & Passive phase \\
\hline${ }^{+} \mathrm{H}_{2} \mathrm{O} / \mathrm{SO}_{2}$ & $315 \pm 78.8(222)$ & $174 \pm 43.5(477)$ \\
\hline${ }^{+} \mathrm{CO}_{2} / \mathrm{SO}_{2}$ & $2.85 \pm 0.17(222)$ & $1.96 \pm 0.12$ \\
\hline${ }^{*} \mathrm{SO}_{2} / \mathrm{HCl}$ & $1.6 \pm 0.22(84)$ & $0.5 \pm 0.07(423)$ \\
\hline
\end{tabular}




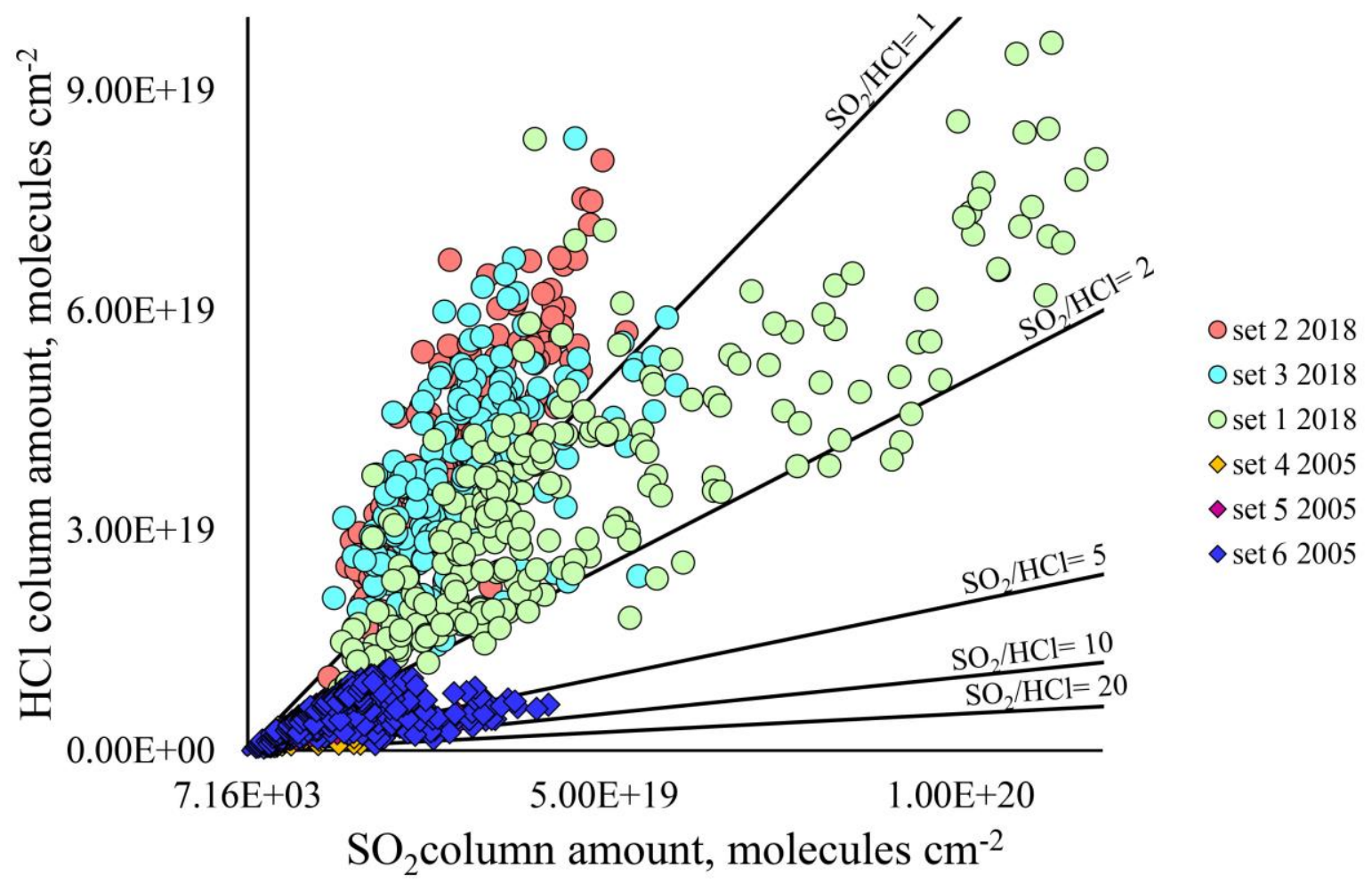

428

429 Figure 6 Column amounts for $\mathrm{SO}_{2}$ and $\mathrm{HCl}$ for spectra from set 1 (green circles; 06:41-06:56 h), 430 set 2 (red circles;08:19-08:24 h) set 3 (blue circles; 08:56-09:03 h) measured all from the same 431 position on the South crater on 16 July 2018 and data from the South crater on 1 January 2005 432 including set 4( yellow diamonds: 09:19-09:22 h), set 5 (pink diamonds: 09.23-09.24 h) and set 6 433 (blue diamonds: 09:24-.09:25 h) (Oppenheimer et al., 2006). Solid lines indicate the $\mathrm{SO}_{2} / \mathrm{HCl}$ 434 ratios. Passive degassing is characterised by $\mathrm{HCl}>\mathrm{SO}_{2}$ whereas active degassing has higher $\mathrm{SO}_{2}$ 435 concentrations $\left(\mathrm{SO}_{2}>\mathrm{HCl}\right)$. Higher ratios indicate a higher proportion of explosive gas. Set 1 is 436 compared to set 2 and set 3 a period of higher activity. (Average $\mathrm{HCl}$ error: $\pm 7 \%$ and $\mathrm{SO}_{2}$ error: $437 \pm 4.8 \%)$.

\subsection{Volcanic gas fluxes}

In table 4 we show the flux of $\mathrm{SO}_{2}, \mathrm{CO}_{2}$ and $\mathrm{HCl}$ from Yasur Volcano in 2018, derived from UV camera data (Ilanko et al., 2020) and from the Multi-GAS and FTIR molar ratios (table 2) compared to those of other basaltic open vent volcanoes known for their Strombolian activity.

442 The mean $\mathrm{SO}_{2}$ flux has been measured as $7.9 \mathrm{~kg} \cdot \mathrm{s}^{-1}$ (Bani and Lardi, 2007), $7.9 \mathrm{~kg} \cdot \mathrm{s}^{-1}$ (Metrich et al., 2011) and $4.9 \mathrm{~kg} \mathrm{~s}^{-1}$ used in this study (Ilanko et al., 2020).

444 Combining the flux measured in 2018 with the mean mass ratios in the gas plume (table 2 and 445 the average $\mathrm{SO}_{2} / \mathrm{HCl}$ value of 1.02$)$ we calculate daily fluxes of $7.5 \mathrm{~kg} \cdot \mathrm{s}^{-1} \mathrm{CO}_{2}( \pm 16.2 \%), 208$ $\mathrm{kg} \cdot \mathrm{s}^{-1} \mathrm{H}_{2} \mathrm{O}( \pm 29.2 \%)$ and $4.8 \mathrm{~kg} \cdot \mathrm{s}^{-1} \mathrm{HCl}( \pm 13.6 \%)$. In 2007 the corresponding fluxes were 9.7

$447 \mathrm{~kg} \cdot \mathrm{s}^{-1} \mathrm{CO}_{2}\left(29 \%\right.$ higher than in 2018), the $\mathrm{HCl}$ flux was $1.9 \mathrm{~kg} \cdot \mathrm{s}^{-1}$ (60\% lower than in 2018) 448 and the $\mathrm{SO}_{2}$ flux was $7.9 \mathrm{~kg} \cdot \mathrm{s}^{-1}$ (61 \% higher than in 2018). We compare the active and passive 
$\mathrm{CO}_{2} / \mathrm{SO}_{2}$ and $\mathrm{SO}_{2} / \mathrm{HCl}$ ratios with the overall mean ratios in order to get an estimate of the

450 amount of gas supplied by active rather than passive degassing. For example, the mean molar

$451 \mathrm{CO}_{2} / \mathrm{SO}_{2}$ is 2.14 and the gases emitted during active degassing periods have a $\mathrm{CO}_{2} / \mathrm{SO}_{2}$ of 2.85

452 and the passive degassing periods 1.96. Active degassing therefore provides $20 \%$ of the total

453 gas flux. The same value (20\%) is derived using the overall mean molar $\mathrm{CO}_{2} / \mathrm{SO}_{2}$ of 2.14 and

454 the active and passive degassing ratios (2.85 and 1.96). $\mathrm{An} \mathrm{SO}_{2}$ flux of $4.9 \pm 0.74 \mathrm{~kg} \cdot \mathrm{s}^{-1}$ is the 455 same as $423 \pm 63$ tonnes of $\mathrm{SO}_{2}$ per day, of which only $~ 85$ tonnes per day is derived from 456 active degassing, the rest passive degassing. Using a bubble burst frequency of every 0.02 457 seconds; we infer a bubble volume of $14250 \mathrm{~m}^{3}$.

Table 4: Average volcanic gas composition (molar ratios) and fluxes (in $\mathrm{kg} \cdot \mathrm{s}^{-1}$ ) emitted from Yasur Volcano, Vanuatu, in July 2018 Stromboli (Italy), Villarrica (Chile) and Masaya (Nicaragua).

\begin{tabular}{|c|c|c|c|c|c|}
\hline & & $\begin{array}{l}\text { Yasur, } \\
\text { Vanuatu }\end{array}$ & $\begin{array}{l}\text { Stromboli, } \\
\text { Italy }\end{array}$ & $\begin{array}{l}\text { Villarrica, } \\
\text { Chile }\end{array}$ & $\begin{array}{l}\text { Masaya, } \\
\text { Nicaragua }\end{array}$ \\
\hline \multirow[t]{3}{*}{ Molar ratios } & $\mathrm{CO}_{2} / \mathrm{SO}_{2}$ & $2.22 \pm 0.13^{a}$ & $\begin{array}{l}5.7^{\mathrm{c}} \pm 0.34- \\
8^{\mathrm{g}} \pm 0.48\end{array}$ & $\begin{array}{c}1.5^{\mathrm{e}} \pm 0.09 \\
1.7^{\mathrm{e}} \pm 0.11\end{array}$ & $2.7 \pm 0.3^{f}$ \\
\hline & $\mathrm{H}_{2} \mathrm{O} / \mathrm{SO}_{2}$ & $148 \pm 48^{\mathrm{a}}$ & $\begin{array}{l}26.7^{\mathrm{c}} \pm 6.7- \\
48.8^{\mathrm{g}} \pm 5.7\end{array}$ & $\begin{array}{l}67^{\mathrm{e}} \pm 16.8- \\
75^{\mathrm{e}} \pm 18.8\end{array}$ & $63 \pm 7^{\mathrm{f}}$ \\
\hline & $\mathrm{SO}_{2} / \mathrm{HCl}$ & $1.0 \pm 0.14^{\mathrm{a}}$ & $\begin{array}{l}1.00^{\mathrm{h}} \pm 0.08- \\
1.50^{\mathrm{h}} \pm 0.12\end{array}$ & $3 \pm 0.1^{\mathrm{i}}$ & $2 \pm 0.03^{f}$ \\
\hline \multirow[t]{5}{*}{ Mass fluxes } & $\mathrm{SO}_{2}$ & $4.9 \pm 0.74^{b}$ & $\begin{array}{l}0.7^{\mathrm{d}} \pm 0.12- \\
3.0^{-} \pm 0.45^{\mathrm{g}}\end{array}$ & $\begin{array}{l}1.5^{\mathrm{e}} \pm 0.18 \\
3.7^{\mathrm{i}} \pm 0.56\end{array}$ & $7.9 \pm 2.37^{f}$ \\
\hline & $\mathrm{HCl}$ & $4.8 \pm 1.01^{\mathrm{a}}$ & $0.4^{\mathrm{d}, \mathrm{h}}-1.1^{\mathrm{g}, \mathrm{h}}$ & $0.3^{\mathrm{e}, \mathrm{i}}-0.7^{\mathrm{i}}$ & $2.2^{f}$ \\
\hline & $\mathrm{CO}_{2}$ & $7.5 \pm 1.20^{\mathrm{a}}$ & $2.6^{\mathrm{c}} \cdot \mathrm{d}-15.8^{\mathrm{h}}$ & $1.5^{\mathrm{e}}-4.1^{\mathrm{i}}$ & $13.9^{\mathrm{f}}$ \\
\hline & $\mathrm{H}_{2} \mathrm{O}$ & $208^{\mathrm{a}}$ & $5.2^{\mathrm{c}, \mathrm{d}}-41.2^{\mathrm{h}}$ & $28.3^{\mathrm{e}}-78.0^{\mathrm{e}, \mathrm{i}}$ & $140^{\mathrm{f}}$ \\
\hline & Total gas & 225 & $8.9-61.1$ & $31.6-86.5$ & 164 \\
\hline
\end{tabular}

461

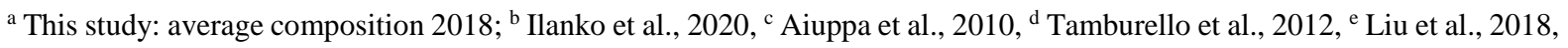

${ }^{\mathrm{f}}$ Martin et al., 2010. ${ }^{\mathrm{g}}$ Allard ,2010, ${ }^{\text {h }}$ Burton et al., 2007, ${ }^{\text {i }}$ Sawyer et al., 2011, 
468

469

470

471

472

473

474

475

476

477

478

479

480

481

482

483

484

485

486

487

488

489

490

491

492

493

494

495

496

497

498

499

500

\subsection{Gas evolution and outgassing in a crystal-rich conduit}

We use geochemical data from Yasur's primitive melt inclusions in olivines (Metrich et al., 2011) to generate a model of closed system magma degassing and compare it with the measured gas composition at the surface (table 3) to infer the approximate pressure of last gas-melt equilibration, which may be equivalent to the gas segregation pressure, for active and passive modes of degassing. Extensive petrological study of Yasur magmas has led to a model (figure 7; table 5) whereby primitive basaltic magmas enter the system at depths of $>6 \mathrm{~km}$ containing $\sim 2500 \mathrm{ppm} \mathrm{CO}_{2}$ (reconstructed from melt inclusion data and volcanic gas ratios; Metrich et al., 2011), $\sim 1 \mathrm{wt} \% \mathrm{H}_{2} \mathrm{O}, 0.1 \mathrm{wt} \% \mathrm{~S}$ and $\sim 550 \mathrm{ppm} \mathrm{Cl}$. We use the $\mathrm{S}$ contents of the melt inclusions and the mean $\mathrm{CO}_{2} / \mathrm{SO}_{2}$ of the gas plume in 2018 to estimate a 'primary' (pre-degassing) melt $\mathrm{CO}_{2}$ content. Using an average sulfur content of melt inclusions of 0.1 wt. \% (Metrich et al., 2011 ) and the average $\mathrm{CO}_{2} / \mathrm{SO}_{2}$ plume mass ratio of 1.5 in July 2018 , we obtain a pre-degassing bulk melt $\mathrm{CO}_{2}$ content of 3000 ppm, assuming complete degassing of sulfur and $\mathrm{CO}_{2}$ on eruption, compared with 2500 ppm estimated by Metrich et al. (2011) using the same method.

At pressures between 330 and $130 \mathrm{MPa}$, the exsolved volatile phase is comprised almost entirely of $\mathrm{CO}_{2}$ (resulting in the molar $\mathrm{CO}_{2} / \mathrm{SO}_{2}$ going to infinity at pressures $>130 \mathrm{MPa}$ in figure 7). The primitive basalt undergoes extensive crystallisation in a magma reservoir between 130 and $50 \mathrm{MPa}$ (melt fraction remaining 0.46) to produce basaltic-trachyandesite (Metrich et al., 2011). Olivine-hosted melt inclusions of basaltic-trachyandesite that are assumed to have originated in this reservoir contain up to $1 \mathrm{wt} . \% \mathrm{H}_{2} \mathrm{O}, 780 \mathrm{ppm} \mathrm{S}, 1200 \mathrm{ppm}$ $\mathrm{Cl}$ and $~ 500 \mathrm{ppm} \mathrm{CO}_{2}$ (Metrich et al., 2011). By this stage $63 \%$ of $\mathrm{S}$, and $43 \%$ of bulk magmatic water content has been lost to the vapour phase. The exsolved volatile phase existing in equilibrium with the basaltic trachyandesite melt at this pressure has a molar $\mathrm{CO}_{2} / \mathrm{SO}_{2}$ of $\sim 2.6$, and molar $\mathrm{SO}_{2} / \mathrm{HCl}>100$ (figure 7; table 5).

Between $50 \mathrm{MPa}(\sim 2 \mathrm{~km})$ and the surface ('stage II' of Metrich et al., 2011), S and Cl degas from the melt (table 5; figure 7). At the end of this stage, $29 \%$ of the $\mathrm{Cl}, 86 \%$ of the bulk $\mathrm{S}$, and $90 \%$ of the bulk water has been lost from the magma (Metrich et al., 2011). The exsolved volatile phase is expected to have a molar $\mathrm{CO}_{2} / \mathrm{SO}_{2}$ of $\sim 1.8-2.0$ in this pressure interval, and a molar $\mathrm{SO}_{2} / \mathrm{HCl}$ of 2-6 (figure 7; table 5). On eruption (stage III), an additional 40\% of $\mathrm{Cl}$ exsolved into a vapour phase, as well as an additional $8 \% \mathrm{~S}$ and $4 \% \mathrm{H}_{2} \mathrm{O}$. This low pressure 
501 gas is highly enriched in $\mathrm{HCl}$, generating a molar $\mathrm{SO}_{2} / \mathrm{HCl}$ of $<3$, with a molar $\mathrm{CO}_{2} / \mathrm{SO}_{2}$ of

$502 \quad 1.7$ to 2 (table 5; figure 7).

503

504 Table 5 Yasur's melt composition from primitive melt inclusions (Metrich et al., 2011) and the

505 calculated emitted amount and gas composition for degassing stage I,II, and III in a closed degassing

506 system. The melt fraction in each stage was used to calculate the crystal fraction at each stage (1-f) and

507 incorporate fractional crystallization in the melt degassing process.

\begin{tabular}{|c|c|c|c|c|c|c|c|c|c|c|c|c|c|c|}
\hline \multirow[t]{2}{*}{ Stage } & \multicolumn{2}{|c|}{ Pressure, MPa } & \multicolumn{5}{|c|}{ Melt, wt $\%$} & \multirow{2}{*}{$\frac{\mathrm{f} \text {, melt fraction }}{\mathbf{K}_{2} \mathbf{O}_{0} / \mathbf{K}_{2} \mathbf{O}}$} & \multicolumn{4}{|c|}{ Amount degassed, ppm } & \multicolumn{2}{|c|}{$\begin{array}{l}\text { Volcanic gas ratios, } \\
\text { molar }\end{array}$} \\
\hline & $\operatorname{Max}$ & Min & $\mathrm{CO}_{2}$ & $\mathbf{H}_{2} \mathbf{O}$ & $\mathbf{S}$ & $\mathbf{C l}$ & Comp & & $\Delta \mathrm{CO}_{2}$ & $\Delta \mathrm{H}_{2} \mathrm{O}$ & $\Delta \mathbf{S}$ & $\Delta \mathrm{Cl}$ & $\mathrm{CO}_{2} / \mathrm{SO}_{2}$ & $\mathrm{SO}_{2} / \mathrm{HCl}$ \\
\hline & 330 & 180 & 0.25 & 0.8 & 0.099 & 0.055 & bas & 1 & 0 & 0 & 0 & 0 & $\infty$ & $\infty$ \\
\hline I & 130 & 110 & 0.05 & 1.2 & 0.078 & 0.1235 & $\begin{array}{l}\text { bas-trach- } \\
\text { and }\end{array}$ & 0.46 & 4934 & 5391 & 1370 & 10 & 2.6 & 152 \\
\hline II & 100 & 50 & 0.005 & 1.2 & 0.033 & 0.091 & $\begin{array}{l}\text { bas-trach- } \\
\text { and }\end{array}$ & 0.43 & 5763 & 6605 & 1972 & 369 & 2.1 & 5.9 \\
\hline III & 50 & 0 & 0.001 & 0.2 & 0.006 & 0.046 & $\begin{array}{l}\text { bas-trach- } \\
\text { and }\end{array}$ & 0.35 & 7132 & 2087 & 2768 & 1111 & 1.9 & 2.8 \\
\hline
\end{tabular}

509 We compare our gas data (table 3) as well as previously published data (Merich et al., 2011)

510 to the model (figure 7). The gas compositions for passive degassing are consistent with gases

511 being derived predominantly from the shallowest parts of the conduit system, at pressures of

$512<10 \mathrm{MPa}$ (depths approximately <400 m). These gases are relatively enriched in $\mathrm{HCl}$ and have

513 the lowest $\mathrm{CO}_{2} / \mathrm{SO}_{2}$ values. During the 'active' degassing (Strombolian explosions and

514 spattering), the gases become depleted in $\mathrm{HCl}$ and more $\mathrm{CO}_{2}$-rich, consistent with their

515 derivation from deeper in the conduit, perhaps down to 0.6 to $2 \mathrm{~km}$ depth (figure 7).

516

517 


\section{Volcanic gas composition, mol}

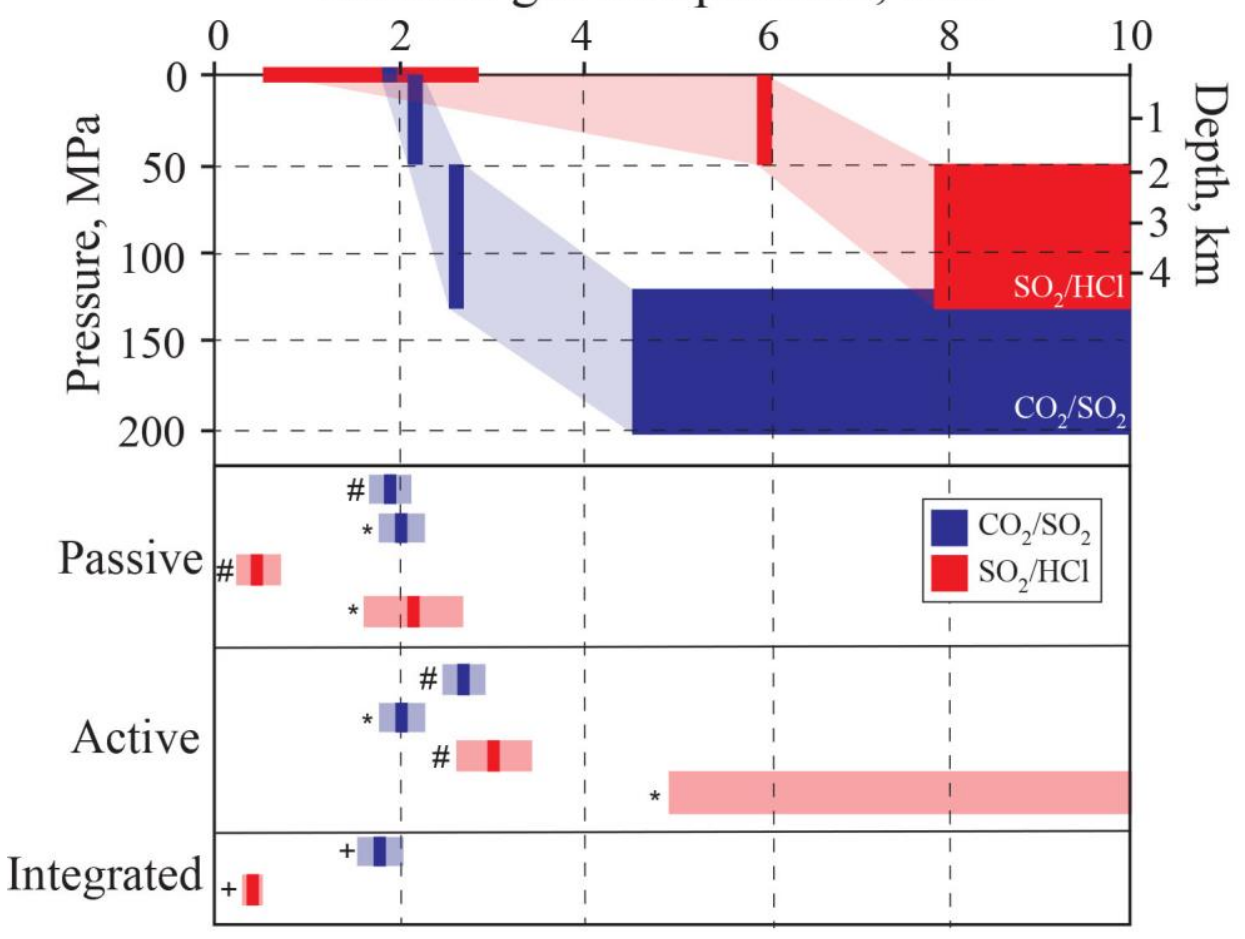

519 Figure 7 Predicted volcanic molar gas composition from melt inclusion data with pressure and 520 depth for Yasur Volcano, reconstructed from melt inclusion data (Metrich et al., 2011). Molar $521 \mathrm{CO}_{2} / \mathrm{SO}_{2}$ is shown in blue, and molar $\mathrm{SO}_{2} / \mathrm{HCl}$ in red. Depths are estimated using a crustal density of $2800 \mathrm{~kg} \cdot \mathrm{m}^{-3}$. Bottom: volcanic gas compositions measured at Yasur for passive degassing, active degassing (Strombolian activity) and measurements taken integrated over both passive and active periods. $\mathrm{S}_{1}-\mathrm{S}_{3}$ stands for different stages proposed in Metrich et al., 2011. Symbols denote data source. \#: this study; *: Oppenheimer et al., 2006; +: Metrich et al., 2011. The dark rectangle denotes the mean value and the light shaded rectangle the range in probable values.

529 Petrological studies have shown that between 6 and $1.8 \mathrm{~km}$ depth, the basaltic parent magma crystallises by $>46$ vol. \% (Metrich et al., 2011) to produce the basaltic trachyandesites that are erupted. Erupted magmas contain around 30 vol. \% crystals (predominantly plagioclase phenocrysts up to $5 \mathrm{~mm}$ in size, and minor olivine, clinopyroxene and Fe-oxides; Metrich et al., 2011), which suggests that significant volumes of crystals (dominantly olivine) must accumulate in a subsurface mush pile. Extensive crystallisation in the upper 1-2 $\mathrm{km}$ of the conduit, driven by water degassing, induces changes in the rheological properties of the magma. We use the Giordano et al. (2008) viscosity model with a typical melt inclusion composition from Metrich et al. (2011) and a $\mathrm{H}_{2} \mathrm{O}$ content of $1.1 \mathrm{wt} \%$ for pre-degassing and 0.2 wt. \% after degassing. Based on the MELTS output the crystallinity increases from 10 to

53932 vol. \% on degassing. We find that the bulk magma effective viscosity increases from 5.8 $540 \times 10^{2} \mathrm{~Pa} \cdot \mathrm{s}$ prior to degassing to $1.5 \times 10^{5} \mathrm{~Pa} \cdot \mathrm{s}$ after degassing and crystallisation. 
542 In line with recent studies showing how the exsolved gas phase interacts with the crystal phase

543 (Belien et al., 2010, Parmigiani et al., 2014, 2016, 2018, Oppenheimer et al., 2015,2020,

544 Pistone et al., 2017, Barth et al., 2019, Spina et al., 2019b, ), we suggest that the increase in

545 the crystallinity and bulk viscosity of the magma creates a plug at the top of the conduit that

546 develops an effective yield strength (figure 8). Our hypothesis is consistent with previous work:

547 Kremers et al., (2012) suggested that a degassed, viscous plug may exist in the upper conduit

548 of Yasur, based on the observed mingling of sideromelane and microlite-rich tachylite. We

549 envisage Yasur's shallow conduit consisting of a crystal-rich region with a thickness of at least

5500.6 and up to $2 \mathrm{~km}$, if extensive crystallization is driven by $\mathrm{H}_{2} \mathrm{O}$ degassing (Metrich et al.,

551 2011). Magmatic gas bubbles (with a slight $\mathrm{CO}_{2}$-enrichment over gases closer to the surface,

552 and poor in $\mathrm{HCl}$ ) will accumulate in the crystal-rich plug, before generating a local

553 overpressure that is sufficient to overcome the yield strength of the overlying crystal plug

554 (figure 8a). The gas bubble will then migrate upward (figure 8b, c) and transport magma in

555 its wake (Del Bello et al., 2015). At the surface, the bubble bursts as a typical Strombolian

556 eruption with a gas phase enriched in $\mathrm{CO}_{2}$ compared to $\mathrm{SO}_{2}$ (figure 8d). The plug rebuilds and

557 bubbles begin to get trapped again and a new cycle starts (figure 8g). Bubbles released during

558 'passive degassing are sourced from close to the surface and in general, these shallow gases

559 are richer in $\mathrm{HCl}$ than the deeper accumulated gases due to the fact that $\mathrm{HCl}$ exsolves at 560 pressures $<10 \mathrm{MPa}$.

561

562

\subsection{Degassing rates and magma fluxes}

563 We may calculate the net upward flux of magma in the conduit required to supply the observed

564 fluxes of $\mathrm{SO}_{2}$ at the surface (table 4). Using the maximum pre-eruptive sulphur concentrations

565 of $1000 \mathrm{ppm}$ in primitive olivine-hosted melt inclusions (Metrich et al., 2011) and mean $\mathrm{SO}_{2}$

566 fluxes of $4.9 \mathrm{~kg} \cdot \mathrm{s}^{-1}$ measured in the time periods of $6^{\text {th }}$ to $9^{\text {th }}$ July 2018 (Ilanko et al., 2020), we

567 infer a magma supply rate $\sim 2450 \mathrm{~kg} \cdot \mathrm{s}^{-1}$, for a magma mean density of $2650 \mathrm{~kg} \cdot \mathrm{m}^{-3}$ and a crystallinity of $32 \mathrm{vol}$. \%. Our calculated bulk magma degassing rate of $2450 \mathrm{~kg} \cdot \mathrm{s}^{-1}$ is lower than previous estimates of magma degassing rate of $4100 \mathrm{~kg} \cdot \mathrm{s}^{-1}$ (Metrich et al, 2011). We assume in this calculation that the magma degasses all of its sulfur (the $\mathrm{S}$ concentration in the erupted glass matrix is 0.006 wt.\%). Yasur volcano has been degassing for the last 1400 years

572 (Vergniolle and Metrich, 2016). Over long timescales the flux of degassing (but not necessarily 573 erupted) magma is $\sim 0.04 \mathrm{~km}^{3}$ per year, with a minimum of $54 \mathrm{~km}^{3}$ degassed magma 
574 presumably stored as a plutonic body at depth over 1400 years, consistent with previous 575 estimates $\left(0.05 \mathrm{~km}^{3}\right.$ per year; Metrich et al., 2011).

576

577 These new data from Yasur volcano in 2018 provide insights into the influence of crystals on 578 bubble formation events in the shallow conduit. These crystals may form a viscous plug that 579 influences bubble formation depth and consequently their chemical fingerprint. It is known that 580 magma in the shallow conduit of other Strombolian active volcanoes is crystal-rich, with 30 to 58160 vol. \%. This crystal content might be high enough to develop an effective yield strength to 582 trap bubbles and form slugs.

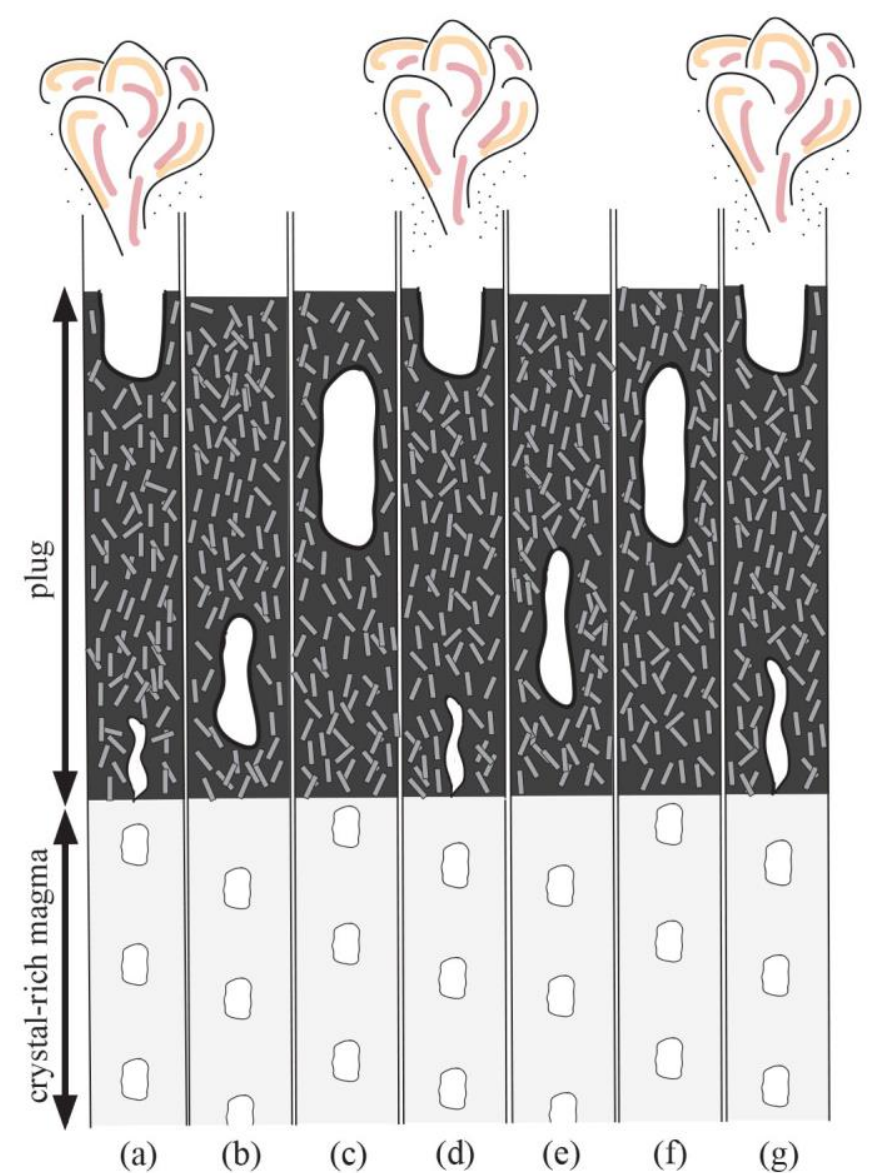

(a)

(b)

(c)

(d)

(e)

(f)

(g) 


\section{Conclusions}

593 We present volcanic gas flux and composition data from Yasur Volcano, Vanuatu, during a 594 field campaign in July 2018. We draw the following conclusions:

595

596

597

598

599

600

601

602

603

604

605

606

607

608

609

610

611

612

613

614

615

616

617

618

619

620

621

622

623

624

(1) The average volcanic plume chemistry is characterised by a mean molar $\mathrm{CO}_{2} / \mathrm{SO}_{2}$ ratio of $2.12, \mathrm{H}_{2} \mathrm{O} / \mathrm{SO}_{2}$ of 148 and $\mathrm{SO}_{2} / \mathrm{HCl}$ of 1.0 . The mean $\mathrm{SO}_{2}$ flux is $4.9 \mathrm{~kg} \cdot \mathrm{s}^{-1}$. Therefore, the mean fluxes of the other species are $7.5 \mathrm{~kg} \cdot \mathrm{s}^{-1} \mathrm{CO}_{2}, 208 \mathrm{~kg} \cdot \mathrm{s}^{-1} \mathrm{H}_{2} \mathrm{O}$ and $4.8 \mathrm{~kg} \cdot \mathrm{s}^{-1} \mathrm{HCl}$.

(2) The degassing regime at Yasur Volcano, as also defined from previous studies (Oppenheimer et al., 2007; Metrich et al., 2011) ranges from 'passive' to 'active' styles, with the latter characterised by strombolian explosions. These styles are also distinguished by their characteristic gas compositions in July 2018: (a) gases emitted during active degassing are enriched in $\mathrm{SO}_{2}$ and $\mathrm{CO}_{2}$ with $\mathrm{CO}_{2} / \mathrm{S}$ ratios of $2.85 \pm 0.17$, $\mathrm{SO}_{2} / \mathrm{HCl}$ with $1.6 \pm 0.22$ and $\mathrm{H}_{2} \mathrm{O} / \mathrm{SO}_{2}$ with $315 \pm 78.8$ (b) passive degassing is enriched in $\mathrm{HCl}$ with $\mathrm{CO}_{2} / \mathrm{SO}_{2}$ ratios of $1.96 \pm 0.12, \mathrm{SO}_{2} / \mathrm{HCl}$ with $0.50 \pm 0.07$ and $\mathrm{H}_{2} \mathrm{O} / \mathrm{SO}_{2}$ of $174 \pm 43.5$.

(3) In order to understand the physical and chemical characteristics of the passive and active degassing at Yasur, we consider the gas compositions in the context of a volatile degassing model derived from melt inclusion studies (Metrich et al., 2011). We envisage Yasur's shallow conduit consisting of a crystal-rich region with a thickness of at least $0.6 \mathrm{~km}$, and up to $2 \mathrm{~km}$ from the surface. Magmatic gas bubbles (with a slight $\mathrm{CO}_{2}$-enrichment over gases closer to the surface, and poor in $\mathrm{HCl}$ ) accumulate at the base of the crystal-rich plug, before generating a local overpressure that is sufficient to overcome the yield strength of the overlying crystal plug.

\section{Acknowledgements}

We thank the Vanuatu Meteorology and Geohazards department for their collaboration and support for during access and permission performing a field campaign at Yasur Volcano. Furthermore, we gratefully acknowledge the loan of equipment to carry out this research from the Natural Environment Research Council Field Spectroscopy Facility and their help in during the fieldwork when any questions arose. We also thank Kelson and Rodga from Jungle Oasis for their help during our stay on Tanna island. This work was supported by the Natural 
625 Environment Research Council (grant number NE/L002507/1), by the postgraduate travel 626 funds received from Fitzwilliam College, by the Elspeth Matthews grant given by the Royal 627 Geological Society, by the Mary Euphrasia Mosley, Sir Bartle Frere and Worts travel fund 628 report given by the University of Cambridge and by the Exzellenzstipendium received by 629 WKO. A.A. acknowledges funding support from the Alfred P. Sloan Foundation via the Deep 630 Carbon Observatory (UniPa-CiW subcontract 10881-1262) and from MIUR (under grant $\mathrm{n}$. 631 PRIN2017-2017LMNLAW). T.D.P. acknowledges the support of the Royal Society 632 (RG170226). TI is a Commonwealth Rutherford Fellow, funded by the UK government. We

633

634

635

636

637

638

639

640

641

642

643

644

645

646

647

648

649

650

651

652

653

654

655

656

657

658

659

660

661

662

663

664

665

666 thank two anonymous reviewers, whose helpful comments improved the manuscript enormously.

\section{References}

Aiuppa, A., Guidice, G., Gurrieri, S., Liuzzo, M., Burton, M., Caltabiano, T., McGonigle, A,J.S., Salerno, G., Shinohara, H., Valenza, M., 2008. Total volatile flux from Mount Etna. J. Geophys. Res. Lett. 35, L24302

Aiuppa, A., Bertagnini, A., Metrich, N., Moretti, R., Di Muro, A., Liuzzo, M., Tamburello, G., 2010. A model of degassing for Stromboli volcano. Earth Planet. Sci. Lett. 294, 195-204.

Aiuppa, A., de Moor, J. M., Arellano, S.,Coppola, D., Francofonte, V., Galle, B., Moretti, R., 2018. Tracking formation of a lava lake from ground and space: Masaya volcano (Nicaragua), 2014-2017. Geochem. Geophys. Geosyst.19, 496-515.

Aiuppa, A., Fischer, T.P., Plank, T., Bani, P., 2019. $\mathrm{CO}_{2}$ flux emissions from the Earth's most actively degassing volcanoes, 2005-2015. Sci. Rep. 9(5442).

Allard, P., Carbonelle, J., Metrich, N., Loyer, H., Zettwoog, P., 1994. Sulphur output and magma degassing budget of Stromboli volcano. Nature 368, 326-330.

Allard, P., Burton, M.R., Mure, F., 2005. Spectroscopic evidence for a lava fountain driven by previously accumulated magmatic gas, Nature 433, 407-410.

Allard, P., $\mathrm{A} \mathrm{CO}_{2}$-rich gas trigger of explosive paroxysms at Stromboli basaltic volcano, Italy. 2010. J. Volcanol. Geotherm. Res. 189, 363-374.

Andres, R.J., Kasgnoc, A.D., 1998. A time-averaged inventory of subaerial volcanic sulfur emissions. , J. Geophys. Res. 103, 25251-25261.

Bani, P., Lardy, M., 2007. Sulphur dioxide emission rates from Yasur volcano, Vanuatu archipelago. Geophys. Res. Lett. 34. 
Bani, P., Harris, A. J.L., Shinohara, H., Donnadieu, F., 2013. Magma dynamics feeding Yasur's explosive activity observed using thermal infrared remote sensing. Geophys. Res. Lett. 40, 3830-3835.

670

671

672

673

674

675

676

677

678

679

680

681

682

683

684

685

686

687

688

689

690

691

692

693

694

695

696

697

698

699

700

701

702

703

704

705

706

707

708

709

710

711

712

713

Barth, A., Edmonds, E., Woods. A.W., 2019. Valve-like dynamics of gas flow through a packed crystal mush and cyclic strombolian explosions. Sci Rep. 9(1), 821.

Batchelor, G.K., 1967. An Introduction to Fluid Dynamics. Cambridge University Press, 615 pp

Battaglia, J., Metaxian, J.P., Garaebiti, E., 2016. Families of similar events and modes of oscillation of the conduit at Yasur volcano (Vanuatu). J. Volcanol. Geotherm. Res. 322, 196211.

Battaglia, J., Métaxian,J.P., Garaebiti ,E., 2016. Short term precursors of Strombolian explosions at Yasur volcano (Vanuatu), Geophys. Res. Lett. 43

Blackburn E.A., Wilson, L., Sparks, R.S.J., 1976. Mechanism and dynamics of Strombolian activity. J.Geol. Soc. Lond. 132, 429-440.

Beckett, F.M., Burton, M., Mader, H.M., Phillips, J.C., Polacci, M., Rust, A.C., Witham, F., 2014. Conduit convection driving persistent degassing at basaltic volcanoes. J. Volcanol. Geotherm. Res. 238, 19-35.

Belien, I.B., Cashmann, K.V., Rempel, A.W., 2010. Gas accumulation in particle-rich suspensions and implications in crystal-rich magma. Earth Planet. Sci. Lett. 297, 133-140.

Bell, R.J., 1972. Introductory Fourier transform spectroscopy. Academic Press, Inc., New York.

Burton, M. R., Oppenheimer,C., Horrock,L.A., Francis, P.W., 2000. Remote sensing of CO2 and $\mathrm{H} 2 \mathrm{O}$ emission rates from Masaya volcano, Nicaragua. Geology 28, 915 - 918.

Burton, M., Allard, P., Mure, F., La Spina, A., 2007a. Magmatic gas composition reveals the source depth of slug-driven Strombolian explosive activity. Science 317, 227-230.

Burton, M.R., Mader, H.M., Polacci, M., 2007b. The role of gas percolation on quiescent degassing of persistently active basaltic volcanoes Earth Planet. Sci. Lett. 262, 46-60.

Burton, M.R., Sawyer, G.M., Granieri, D., 2013. Deep Carbon Emissions from Volcanoes. Rev. Mineral. Geochem.75, 323-354.

Capponi, A., James, M.R., Lane, S.J., 2016. Gas slug ascent in a stratified magma: Implications of flow organisation and instability for Strombolian eruption dynamics. Earth Planet. Sci.435, 159-170.

Carn, S.A., Fioletov, V.E., Mc.Linden, C.A., Li, C., Krotov, N.A., 2017. A decade of global volcanic SO2 emissions measured from space. Sci Rep. 7. 
714 Carney, J., Macfarlane, A., 1979. Geology of Tanna, Aneityum Futana and Aniwa. New

715 Hebrides Gov. Geol. Surv.Rep. 5-29.

716 Chouet, B., Saccorotti, G., Dawson, P., Martini, M., Scarpa, R., DeLuca, G., Milana, G.,

717 Cattaneo, M., 1999. Broadband measure-ments of the sources of explosions at Stromboli

718 volcano, Italy. Geophys. Res. Lett. 26, 1937-1940.

719 Chouet, B., Dawson, P., Ohminato, T., Martini, M.,Saccorotti, G., Giudicepietro, F., De

720 Luca, G., Milana,G., Scarpa, R., 2003. Source mechanisms of explosions at Stromboli

721 Volcano, Italy, determined from moment-tensor inversions of very-long-period data. J.

722 Geophys. Res. 108.

723 Cimarelli, C., Costa, A., Mueller, S., Mader, H.M., 2011. Rheology of magmas with bimodal

724 crystal size and shape distributions: Insights from analogue experiments. Geochem. Geophys.

725 Geosyst.12, 1525-2027.

726

727

728

729

730

731

732

733

734

735

736

737

738

739

740

741

742

743

744

745

746

747

748

749

750

751

752

753

754

755

756

757

758

Coltelli, M., Del Carlo, P., Vezzoli, L., 1995, Stratig-raphy of the Holocene Mt. Etna explosive eruptions: Periodico di Mineralogia, 64, 141-143.

Del Bello, E., Llewellin, E., Taddeucci, J., Scarlato, P., Lane, J. S., 2012. An analytical model for gas overpressure in slug-driven explosions: Insights into Strombolian volcanic eruptions. J.Geophys.Res. 117.

Duffell, H.J., Oppenheimer, C., Pyle, D.M., Galle, B., McGonigle, A.J.S., Burton, M.R., 2003. Changes in gas composition prior to minor explosive eruption at Masaya volcano, Nicaragua. J. Volcanol. Geotherm. Res. 126, 327-339.

Del Gaudio, P., Ventura, G., Taddeucci, J., 2013. The effect of particle size on the rheology of liquid-solid mixtures with the application to lava flows: Results from analogue experiments. Geochem. Geophys. Geosyst.14, 2661-2669.

Francis, P. W., Oppenheimer, C., Stevenson, D., 1993. Endogenous growth of persistently active volcanoes. Nature 366, 554-557.

Francis, P., and Oppenheimer, C., 2004. Volcanoes, $2^{\text {nd }}$ Edition, Oxford University Press, Oxford, $521 \mathrm{pp}$.

Ghiorso, M.S., and Sack, R.O., 1995. Chemical mass transfer in magmatic processes IV. A revised and internally consistent thermodynamic model for the interpolation and extrapolation of liquid-solid equilibria in magmatic systems at elevated temperatures and pressures. Contributions Mineral. Petrol. 1999, 197-212.

Girona, T., Costa, F., Schubert, G., 2015. Degassing during quiescence as a trigger of magma ascent and volcanic eruptions. Sci.Rep. 5, 18212.

Gaudin, D., Taddeucci, J., Scarlato, P., Moroni, M., Freda, C., Gaeta, M., Palladino, D.M., 2014. Pyroclastic tracking velocimetry illuminates bomb ejection and explosion dynamics at Stromboli (Italy) and Yasur (Vanuatu) volcanoes. J.Geophys. Res. 119, 5384-5397. 

U., Ricci, T., Scarlato, P., 2016. 3-D high speed imaging of volcanic bomb trajectory in basaltic explosive eruptions. Geochem. Geophys. Geosyst.17, 4268-4275.

763

764

765

766

767

768

769

770

771

772

773

774

775

776

777

778

779

780

781

782

783

784

785

786

787

788

789

790

791

792

793

794

795

796

797

798

799

800

801

802

803

804

805

806

Gaudin, D., Taddeucci, J., Scarlato, P., Del Bello, E., Ricci, T., Orr, T., Houghton, B., Harris, A.J.L., Rao, S., Bucci, A., 2017. Integrating puffing and explosions in a general scheme for Strombolian-style activity. J. Geophys. Res. Solid Earth 122 (3), 1860-1875.

Getson, J.M., Whittington, A.G., 2007. Liquid and magma viscosity of anorthite-forsteritediopside-quartz systems and implications for the viscosity-temperature paths of cooling magmas. J.Geophys.Res.112.

Griffiths, P.R., 1975. Chemical infrared Fourier transform spectroscopy, Chemical analysis. Wiley, New York.

Gurioli, L., Colo, L., Bollasina, A.J., Harris, A.J.L., Whittington,A., Ripepe, M., 2014. Dynamics of Strombolian explosions: Inferences from field and laboratory studies of erupted bombs from Stromboli volcano, J. Geophys. Res. Solid Earth, 119, 319-345.

Harrocks, L. A., Oppenheimer, C., Burton, M.R., Duffell, H.J., Davies, N.M., Nicholas, A,M., Bell, W., 2001. Open-path Fourier transform infrared spectroscopy of $\mathrm{SO}_{2}$ : An empirical error budget analysis, with implications for volcano monitoring. J.Geophys. Res. 106, 27647-27659.

Harris, A.J.L., Stevenson, D.S., 1997. Magma budgets and a steady-state activity of Vulcano and Stromboli. Geophys. Res. Lett. 24, 1043-1046.

Hort, M., Seyfried, R., Voge, M., 2003. Radar Doppler velocimetry of volcanic eruptions: theoretical considerations and quantitative documentation of changes in eruptive behaviour at Stromboli volcano, Italy. Geophys.J. Int. 154, 515-532.

Houghton, B.F., and Gonnermann, H.M., 2008. Basaltic explosive volcanism: Constraints from deposits and models. Chem Erde-Geochem.68, 117-140.

Houghton, B.F., Taddeucci, J., Andronico, D., Gonnermann, H.M., Pistolesi, M., Patrick, M.R., Orr, T.R., Swanson, D.A., Edmonds, M., Gaudin, D., Carey, R.J., Scarlato, P., 2016. Stronger or longer: discriminating between Hawaiian and Strombolian eruption styles. Geology 44, 163-166.

Huppert, H.E., Hallworth, M.A., 2007. Bi-directional flows in constrained systems. J. Fluid Mech. 578, 95-112.

Ilanko, T., Opppenheimer, C., Burgisser, A., Kyle, P., 2015. Transient degassing events at the lava lake at the lava lake of Erebus volcano. GeoResJ, 7, 43-48.

Ilanko, T., Pering, T.D., Wilkes, T.C., Woitischek, J., D’Alea, R., Aiuppa, A., McGonigle, A.J.S., Edmonds, M., Garaebaeti, E., 2020. Ultraviolet camera measurments of passive and explosive sulphur dioxide emissions at Yasur volcano, Vanuatu. http://eartharxic.org/7r2ay.

Ilyinskaya, E., Martin, R.S., Oppenheimer, C., 2012. Aerosol formations in basaltic lava fountaining: Eyjafjallajökull volcano, Iceland. J.Geophys. Res. 117.

James, M.R., Lane, S.J., Wilson, L., Corder, S.B., 2009. Degassing at low magma-viscosity volcanoes: Quantifying the transition between bubble-burst and Strombolian eruption. J. Volcanol. Geotherm. Res., 180, 81-88. 
Jaupart, C., Vergniolle, S., 1989. The generation and collapse of a foam layer at the roof of a basaltic magma chamber. J. Fluid Mech. 203, 347-380.

Jaupart, C., Vergniolle, S., 1988. Laboratory models of Hawaiian and Strombolian eruptions. Nature 331, 58-60.

Kantzas, E.T., McGonigle, A.J.S., Tamburello, G., Aiuppa, A., Bryant, R.G., 2010. Protocols for UV camera volcanic $\mathrm{SO}_{2}$ measurements. Volcanol. Geotherm. Res. 194, 55-60.

Kazahaya, K., Shinohara, H., Saito, G., 1994. Excessive degassing of Izu-Oshima volcano: magma convection in a conduit. Bull. Volcanol. 56, 207-216.

Kern, C., Luebcke, P., Bobrowski, N., Campion, R., Mori, T., Smekesn, J., Stebel, K., Tamburello, G., Burton, M., Platt, U., Prata, F., 2015. Intercomparison of $\mathrm{SO}_{2}$ camera system for imaging volcanic gas plumes. Volcanol. Geotherm. Res. 300, 22-36.

Kremers, S., Lavallée, Y., Hanson, J., Hess, K. U., Chevrel, M. O., Wassermann, J., Dingwell, D. B., 2012. Shallow magma-mingling-driven Strombolian eruptions at Mt. Yasur volcano, Vanuatu Geophys. Res. Lett. 39(21).

Koyaguchi, T., 1985, Magma mixing in a conduit. J.Volcanol. Geotherm. Res. 25, 365-369.

Koyaguchi, T., 1987, Magma mixing in a squeezed conduit. Earth Planet. Sci. Let. 84, 339744.

Liu, E.J., Wood, K., Mason, E., Edmonds, M., Aiuppa, A., Guidice, G., Bitetto, M., Francofonte, V., Burrow, S., Richardson, T., Watson, M., Pering, T.D., Wilkes, T.C., McGonigle, A.J.S., Velasquez, G., Melgarejo, C., Bucarey, C., 2019. Dynamics of Outgassing and Plume Transport Revealed by Proximal Unmanned Aerial Systems (UAS) Measurements at Volcan Villarrica, Chile. Geochem. Geophys. Geosyst,. 20,730-750.

Louat, R., Hamburger, M., Monizier, M., 1988. Shallow and intermediate-depth seismicity in the New Hebrides arc: Contrains on the subduction process. In: Greene,H.G., Wong, F.L (Eds), Geology and Offshore Resources of Pacific Island Arcs- Vanuatu Region. Circum-Pac. Counc. For energy and Miner. Res., Houston, Tex., earth. Sci. Ser. 8, 329-356.

Martin. R.S., Sawyer, G.M., Spampinato, L., Salerno, G.G., Ramirez, C., Ilyinskaya, I., Witt, M.L.I., Mather, T.A., Watson, I.M., Phillips, J.C., Oppenheimer, C., 2010. A volatile inventory for Masya Volcano, Nicaragua. Geophys. Res. 115, B09215,

Meier, K., Hort, M., Wassermann, J., Garaebiti, E., 2016. Strombolian surface activity regimes at Yasur volcano, Vanuatu, as observed by Doppler radar infrared camera and infrasound. J. Volcanol. Geotherm. Res. 322, 184-195.

Metrich, N., Allard, P., Aiuppa, A., Bani, P., Bertagnini, A., Shinohara, H., Parello,F., Di Muro, A., Garaebiti, E., Belhadj,O., Massare, D., 2011. Magma and volatile supply to post-collapse volcanism and block resurgence in Siwi Caldera (Tanna island, Vanuatu Arc). J.Petrol. 52, 1077-1105. 
Mori, T., Burton, M., 2006. The $\mathrm{SO}_{2}$ camera: A simple, fast and cheap method for ground based imaging of $\mathrm{SO}_{2}$ in volcanic plumes. Geophys. Res. Lett.33.

Mori, T., Burton, M., 2009. Quantification of the gas mass emitted during single explosions on Stromboli with the $\mathrm{SO}_{2}$ camera. J. Volcanol. Geotherm. Res. 188, 395-400.

Neuberg, J., Luckett, R., Ripepe, M., Braun, T., 1994. Highlights from a seismic broadband array on Stromboli volcano. Geophys.Res. Lett. 21, 749-752.

Ntepe, R., Dorel, J., 1990. Observation of seismic volcanic signals at Stromboli Volcano (Italy). J. Volcanol. Geotherm. Res. 43, 235-251.

Oppenheimer, C., 1996. On the role of hydrothermal systems in the transfer of volcanic sulfur to the atmosphere. Geo- phys. Res. Lett. 23, 2057-2060.

Oppenheimer, C., Volcanic degassing, In: The Crust, Vol. 3, Treatise on Geochemistry. 2003. ed. by R.L. Rudnick, H.D. Holland, K.K. Turekian. Elsevier-Pergamon, Oxford, 123-166 .

Oppenheimer, C., Bani, P., Calkins, J.A., Burton, M.R., Sawyer, G.M., 2006. Rapid FTIR sensing of volcanic gases released by Strombolian explosions at Yasur volcano. Applied Physics B, Volume 85, Issue 2-3, 453-460.

Oppenheimer, J., Rust. A.C., Cashman, K.V., Sandnes, B., 2015. Gas migration regimes and outgassing in particle-rich suspensions. Front. Phys. 3:60.

Oppenheimer, J., Capponi, A., Cashman, K.V., Lane, S.J., Rust, A.C., James, M.R., 2020. Analogues experiments on the rise of large bubbles through a solids-rich suspension: A "weak plug" model for Strombolian eruptions. Earth Planet. Sci. Lett 531, 115931.

Patrick, M.R., Harris, A., Ripepe, M., Dehn, J., Rothery, D.A., Calvari, S., 2007. Strombolian explosive styles and source conditions: Insights from thermal (FLIR) video. Bull. Volcanol. 69 (7), 769-784.

Parfitt, E.A., Wilson, L., 1995. Explosive volcanic eruptions:IX. The transition between Hawaiian-style lava fountaining and Strombolian explosive activity. Geophys. J. Int. 121,226232.

Parfitt, E. A., 2004. A discussion of the mechanisms of explosive basaltic eruptions. J. Volcanol. Geotherm. Res. 134, 77-107.

Parfitt, E.A., Wilson, L., 2008. Fundamentals of physical volcanology. Blackwell Publishing Ltd. 230pp.

Parmigiani, A., Huber, C., Bachmann, O., 2014. Mush microphysics and the reactivation of crystal-rich magma reservoirs. J.Geophys. Res. Solid Earth 119, 6308-6322.

Parmigiani, A., Faroughi S., Huber, C., Bachmann, O., Su, Y., 2016. Bubble accumulation and its role in the evolution of the magma reservoirs in the upper crust. Nature 532, 492-495. 
900 Parmigiani, A., Degruyter, W., Leclaire, S., Huber, C., Bachmann, O., 2017. The mechanics 901 of shallow magma reservioir outgassing. Geochem. Geophys. Geosyst. 18, 2887-2905.

902 Patrick, M.R., Harris, A.J.L., Ripepe, M., Dehn, J., Rothery, D., Calvari, S., 2007. Strombolian 903 explosive styles and source conditions: insights from thermal (FLIR) video. Bull. Volcanol. $90469,769-784$.

905 Pering, T.D., Tamburello, G., McGonigle, A.J.S., Aiuppa, A., James, M.R., Lane, S.J., Sciotto, 906 M., Cannata, A., Patane, D., 2015. Dynamics of mild strombolian eruptions on Mt. Etna. J. 907 Volcanol. Geotherm. Res. 300, 103-111.

908

Pering, T.D., McGonigle, A.J.S., 2018. Combining Spherical-Cap and Taylor Bubble Fluid

910 Dynamics with Plume Measurements to Characterize Basaltic Degassing. Geoscience 8 (2), 91142.

912

913

Pioli, L., Bonadonna,C., Azzopardi, B.J., Phillips,J.C., Ripepe, M., 2012. Experimental constraints on the outgassing dynamics of basaltic magmas, J. Geophys. Res. 117, B03204,

Pistone, M., Whittington, A. G., Andrews, B. J., Cottrell, E. 2017. Crystal-rich lava dome extrusion during vesiculation: an experimental study. J. Volcanol.Geotherm. Res. 347, 1-14.

Ripepe, M., Marchetti, E., 2002. Array tracking of infrasonic sources at Stromboli volcano. Geophys. Res. Lett. 29.

Ripepe, M., Rossi, M., Saccorotti, G., 1993. Image processing of explosive activity at Stromboli, J. Volcanol. Geotherm. Res. 54, 335-351.

924 Ripepe, M., Marchetti, E., Ulivieri, G., 2007. Infrasonic monitoring at Stromboli volcano during the 2003 effusive eruption: insights on the explosive and degassing processof an open conduit system. J.Geophys. Res. 112, B09207.

Ripepe, M., Harris, A.J.L., 2008. Dynamics of the 5 April 2003 explosive paroxysm observed at Stromboli by a near-vent thermal, seismic and infrasonic array. Geophys. Res. Lett. 35 , L07306.

Rothman, L.S., Gordon, I.E., Barbe, A., Chris Benner, D., Bernath, P.F., Birk, M., Boudon, V., Brown, L.R., Campargue, A., Champion, J.-P., Chance, K., Coudert, L.H., Dana, V., Devi, V.M., Fally, S., Flaud, J.-M., Gamache, R.R., Goldman, A., Jacquemart, D., Kleiner, I., Lacome, N., Lafferty, W.J., Mandin, J.-Y., Massie, S.T., Mikhailenko, S.N., Miller, C.E., Moazzen-Ahmadi, N., Naumenko, O.V., Nikitin, A.V., Orphal, J., Perevalov, V.I., Perrin, A., Predoi-Cross, A., Rinsland, C.P., Rotger, M., Simeckova, M., Smith, M.A.H., Sung, K., Tashkun, S.A., Tennyson, J., Toth, R.A., Vandaele, A.C., Vander Auwera, 2009. The HITRAN 2008 molecular spectroscopic database. J. Quant. Spectrosc. Radiat. Transfer 110:533-572. 
Shinohara, H., 2005. A new technique to estimate volcanic gas composition: plume measurements with a portable multi-sensor system. J. Volcanol. Geotherm. Res. 143(4), 319948333.

949 Slezin, Y.B., 2003. The mechanism of volcanic eruptions (a steady state approach). J. 950 Volcanol. Geotherm. Res. 122, 7-50.

951

952

953

954

955

956

957

958

959

960

961

962

963

964

965

966

967

968

969

970

971

972

973

974

975

976

977

978

979

980

981

982

983

984

985

986
Sparks, R.S.J., 1978. The dynamics of bubble formation and growth in magmas: A review and analysis. J. Volcanol. Geotherm. Res. 3, 1-37.

Spina, L., Taddeucci, J., Cannata, A., Gresta, S., Lodato, L., Privitera, E., Scarlato, P., Gaeta, M., Gaudin, D., Palladino, D.M., 2016. Explosive volcanic activity at Mt. Yasur: A characterization of the acoustic events (9-12 ${ }^{\text {th }}$ July 2011). J. Volcanol. Geotherm. Res. 322, 174-183. Spina, L., Morgavi, D., Costa, A., Scheu, B., Dingwell, D. B., \& Perugini, D., 2019b. Gas mobility in rheologically-layered volcanic conduits: The role of decompression rate and crystal content on the ascent dynamics of magmas. Earth Planet. Sci. 524, 115732.

Stevenson, D.S., Blake, S., 1998. Modelling the dynamics and thermodynamics of volcanic degassing. Bull. Volcanol. 60, 307-317.

Seyfried, R., Hort, M., 1999. Continuous monitoring of volcanic eruption dynamics: a review of various techniques and new results from a frequency-modulated radar Dopplersystem. Bull. Volcanol. 60, 627-639.

Symonds, R.B., Rose, W.I., Bluth, G.J.S., and Gerlach,T.M., 1994. Volcanic gas studies: Methods, results, and applications ,in Carroll, M.R., et al.,eds., Volatiles in magmas: Reviews in Mineralogy, v. 30, p. 1-66.

Taddeucci. J., Scarlato, P., Capponi, A., Del Bello, E., Cimarelli, C., Palladino, D.M., Keuppers, U., 2012a. High-speed imaging of Strombolian explosions: The ejection velocity of pyroclasts. Geophys.Res.Lett. 39 (L02) 301.

Taddeucci, J., Alatoore-Ibarguengorita, M.A., Moroni, M., Tornetta, L., Capponi, A., Scarlatto, P., Dingwell, D.B., De Rita, D., 2012 b. Physicalparameterization of Strombolian eruptions via experimentally-validated modeling of high-speed observations. Geophys. Res. Lett. 39, L16306.

Tamburello, G., Aiuppa, A., Kantzas, E.P., McGonogle, A.J,S., Ripepe, M., 2012. Passive vs. active degassing modes at an open-vent volcano (Stromboli, Italy). Earth Planet. Sci. Lett. 249360, 106-116.

Tamburello, G., 2015. Ratiocalc: Software for processing data from multicomponent volcanic gas analyzers. Comput.Geosci.82, 63-67.

Taylor, G.A., 1956. Review of volcanic activity in the Territory of Papua-New Guinea-the Solomon and New-Hebrides Islands,1951-1953. Bull.Volcanol., II/XVII, 33-37. 
988 Urbanski, N., Voege, M., Seyfried, R., Ruepke, L., Petersen, T., Hanebuth,T. Hort, M., 2002. 98915 days of continuous activity survey at Stromboli volcano/Italy in late September 2000: 990 Doppler radar, seismicity, infrared, soil humidity, and mapping of the crater region. Int. J. Earth 991 Sci. 91, 712-721.

992

993 Vergniolle, S., Brandeis, G., Marechal. 1996. Strombolian explosions 2: Eruption dynamics 994 determined from acoustic measurements. J. Geophys. Res. 101 (B9), 20449-20466. Vergniolle, 995 S., Ripepe, M., 2008, From Strombolian explosions to fire fountains at Etna Volcano (Italy): 996 What do we learn by acoustic measurement?, in Fluid Motions in Volcanic Conduits: A Source 997 of Seismic and Acoustic Signals, edited by S. J. Lane and J. S. Gilbert, Geol. Soc. Spec.Publ. 998 307, 103-124.

999 Vergniolle, S., Metrich, N., 2016. A bird's eye view of "Understanding volcanoes in the 1000 1001 1002 1003

Walker, G. P. L., Self, S., and Wilson, L., 1984, Tarawera, 1886, New Zealand-A basaltic plinian fissure eruption. J. Volcanol. Geotherm. Res. 21, 61-78.

Williams, S. N., 1983, Plinian airfall deposits of basaltic composition: Geology, 11, 211-214.

Wilkes, C.T., Pering, T.D., McGonigel, A,J.S., Tamburello, G., Willmott, J.R., 2017. A LowCost Smartphone Sensor-Based UV Camera for Volcanic $\mathrm{SO}_{2}$ Emission Measurements. Remote Sens. 2017, 9(1), 27.

Wilkes, T.C., McGonigle, A.J.S., Pering, T.D., Taggart, A.J., White, B.S., Bryant, R.G., Willmott, J.R., 2016. Ultraviolet Imaging with Low Cost Smartphone Sensors: Development and Application of a Raspberry Pi-Based UV Camera. Sensors 16, 1649.

1015 Wilson, L., Head, J.W., 1981. Ascent and eruption of basaltic mag-ma on the Earth and Moon. 1016 J. Geophys. Res. 86, 2971-3001.

1017 Wilson, L., Head, J.W., 1983. A comparison of volcanic eruption processes on Earth, Moon, 1018 Mars, Io and Venus. Nature 302,663-669.

1019 Woods, A.W., and Cardoso, S.S.S., 1997. Triggering basaltic volcanic eruptions by bubblemelt separation. Nature 385, 518-20. 